NBER WORKING PAPER SERIES

\title{
DEPOSIT INFLOWS AND OUTFLOWS IN FAILING BANKS: THE ROLE OF DEPOSIT INSURANCE
}

\author{
Christopher Martin \\ Manju Puri \\ Alexander Ufier \\ Working Paper 24589 \\ http://www.nber.org/papers/w24589
NATIONAL BUREAU OF ECONOMIC RESEARCH 1050 Massachusetts Avenue
Cambridge, MA 02138
May 2018

We thank seminar and conference participants at the Adam Smith Workshops (Paris), AFA Annual Meeting (Philadelphia), Avoiding and Resolving Banking Crises Conference (Amsterdam), Basel Research Task Force Conference (Washington, DC), Biennial International Association of Deposit Insurers Research Conference (Basel), Chicago Financial Institutions Conference, Conference for Banking Development Stability and Sustainability (Santiago), Duke University, Eastern Economic Association Conference (New York), Federal Financial Institutions Examination Council Conference (Arlington), Federal Reserve Short-Term Funding Markets Conference (Washington, DC), Financial Intermediation Research Society Conference (Hong Kong), Fixed Income and Financial Institutions Conference (University of South Carolina), MidAtlantic Research Conference (Villanova University), NBER Corporate Finance Conference (Chicago), NBER Monetary Economics Conference (Cambridge), NYU, Office of Financial Research, and Washington University Corporate Finance Conference (St. Louis) for comments and suggestions. We thank Giuseppe Boccuzzi, Mark Egan, Kinda Hachem, Ali Hortacsu, Rustom Irani, Ed Kane, Diana Knyazeva, Carlos Noton, Glenn Schepens, Philipp Schnabl, Steven L. Schwarcz, Pablo Slutzky, Gunseli Tumer-Alkan, Guillaume Vuillemey, Larry Wall, James Wilcox, and members of the FDIC for comments and helpful feedback. The views expressed herein are those of the authors and do not necessarily reflect the views of the Federal Deposit Insurance Corporation or the National Bureau of Economic Research.

NBER working papers are circulated for discussion and comment purposes. They have not been peer-reviewed or been subject to the review by the NBER Board of Directors that accompanies official NBER publications.

(C) 2018 by Christopher Martin, Manju Puri, and Alexander Ufier. All rights reserved. Short sections of text, not to exceed two paragraphs, may be quoted without explicit permission provided that full credit, including $\odot$ notice, is given to the source. 
Deposit Inflows and Outflows in Failing Banks: The Role of Deposit Insurance

Christopher Martin, Manju Puri, and Alexander Ufier

NBER Working Paper No. 24589

May 2018

JEL No. D12,G01,G21,G28

\begin{abstract}
Using unique, daily, account-level balances data we investigate deposit stability and the drivers of deposit outflows and inflows in a distressed bank. We observe an outflow of uninsured depositors from the bank following bad regulatory news. We find that government deposit guarantees, both regular deposit insurance and temporary deposit insurance measures, reduce the outflow of deposits. We also characterize which accounts are more stable (e.g., checking accounts and older accounts). We further provide important new evidence that, simultaneous with the run-off, gross funding inflows are large and of first-order impact - a result which is missed when looking at aggregated deposit data alone. Losses of uninsured deposits were largely offset with new insured deposits as the bank approached failure. We show our results hold more generally using a large sample of banks that faced regulatory action. Our results raise questions about depositor discipline, widely considered to be one of the key pillars of financial stability, raising the importance of other mechanisms of restricting bank risk taking, including prudent supervision.
\end{abstract}

Christopher Martin

Federal Deposit Insurance Corporation 550 17th St NW

Washington DC 20429

chrmartin@fdic.gov

Manju Puri

Fuqua School of Business

Duke University

100 Fuqua Drive

Durham, NC 27708-0120

and FDIC

and also NBER

mpuri@duke.edu
Alexander Ufier

Federal Deposit Insurance Corporation

550 17th St NW

Washington, DC 20429

aufier@fdic.gov 


\section{Introduction}

There were many bank failures during and after the financial crisis of 2007-2009. In this period, many systemically important institutions, as well as numerous smaller firms, faced severe liquidity stress. The inability of financial institutions to maintain stable funding sources was central to the crisis, which resulted in the high-profile failure or near failure of many financial institutions and unprecedented emergency liquidity support by governments around the world. Large quantities of deposits exited from failing banks, prompting a host of academic studies and regulatory responses attempting to find ways to reduce illiquidity and funding stress.

Many governments extended the scope and limit of deposit insurance in an effort to reduce deposit outflows during the crisis; in the US, deposit insurance was increased from $\$ 100,000$ to $\$ 250,000$, and other countries, such as the UK, took similar measures. At the same time, governments introduced temporary deposit insurance measures, such as the Transaction Account Guarantee (TAG) Program, which removed the cap for deposit insurance coverage for many deposit accounts in the US during the crisis. New post-crisis liquidity regulation advocated by Basel requires that banks maintain adequate "stability-adjusted" funding consistent with their "liquidity-adjusted" assets. For such liquidity regulations to be effective, they must accurately characterize the stability of various funding sources. Despite the importance of these measures, there is little academic empirical evidence on whether deposit insurance matters; what deposits are stable; or whether we need to look beyond the focus on deposit outflows to inflows and how this might affect our thinking on liquidity requirements.

In this paper we make a first attempt at answering the following questions: How effective was deposit insurance - both regular deposit insurance as well as temporary measures such as TAG - in preventing the outflow of deposits? What kind of depositors withdraw? How stable are different kinds of deposits? Do depositors discipline banks and, if so, is it effective? While the focus of attention by academicians and regulators alike has been on deposit outflows, what about deposit inflows - are they material? How appropriate are key assumptions of the new liquidity regulations such as the Liquidity Coverage Ratio (LCR) and Net Stable Funding Ratio (NSFR)?

We use a unique, highly granular dataset to assess the impacts of these liquidity-related policy interventions on funding stability, with a particular focus on deposit insurance; in the process, we also uncover a number of other interesting results on the drivers of deposit(or) stability. The data we use were collected by the FDIC from a US bank 1 shortly after

\footnotetext{
${ }^{1}$ Throughout, unless otherwise noted, we use the term "bank" to refer to any insured depository insti-
} 
its failure, and they allow us to measure daily, account-level balances and attributes for several years. Importantly, unlike with aggregated data such as Call Reports, we are able to separately assess inflows and outflows - a distinction that turns out to be of first-order importance. We then generalize our results by studying a large panel of US banks that faced regulatory action.

It is especially illuminating to consider gros ${ }^{2}$ funding outflows and inflows separately. Essentially all prior research, lacking such a detailed dataset, can focus only on net flows; our finding of depositor run-in demonstrates that focusing on net flows is insufficient. Our separate consideration of gross outflows and inflows gives rise to our first two sets of results.

We first examine outflows in our daily-frequency data using Cox hazard models (in addition to probits and linear probability models). We find that FDIC insurance and other government guarantees, including temporary measures such as TAG, significantly reduce the withdrawals of insured depositors in response to ailing bank health. Our results thus support the notion that deposit insurance - even temporary measures which one might worry are not well-understood by depositors - does indeed improve funding stability. We additionally find connections between account characteristics and deposit stability, in that checking accounts are more stable than savings accounts, and depositors receiving regular direct deposits such as payroll are less likely to leave the bank. We also find that depositors who have been with the bank longer are less likely to exit, even when faced with bad regulatory news. Next, our evidence supports the finding that term deposits, which explicitly have withdrawal restrictions, were more risk sensitive and less "sticky" than (demandable) transaction deposits. This is at odds with many economists' intuition, but likely reflects the relative sophistication of term depositors and the inherently forward-looking nature of a non-demandable deposit. Finally, we show that when uninsured depositors leave the bank under stress, they typically withdraw a large share even of insured funds. This result is especially relevant for financial stability, as even a substantial share of banks' insured funding may flee in response to bad news.

Next, we study deposit inflows. To the best of our knowledge, we are the first to show

tution, whether it be a commercial bank, thrift, or credit union. We use the term "financial institution" when needed, which includes the term "bank," as well as institutions such as non-bank finance companies, insurance companies, hedge funds and other entities often referred to as "shadow banks."

${ }^{2}$ We use the term "gross" somewhat loosely here. When we refer to gross outflows, we are actually referring to the net change in funding from existing depositors. Gross inflows refer to net changes in funding from new depositors. Especially in periods of stress, existing depositors almost exclusively flee the bank (i.e., they generate few gross inflows) and new depositors continue arriving (generating few gross outflows), such that our use of the term "gross" functionally coincides with its traditional definition. 
that in the presence of government guarantees, gross funding inflows are of first-order impact - even in imminently failing banks. The failed bank we study was able to replace about a third of its deposit base in the last year of its life, while it was publicly known to be under supervisory scrutiny for its declining condition. About half of these new deposits arrived in the last ninety days before failure, after public regulatory reports showed the bank to be critically undercapitalized. The bank attracted these deposits almost exclusively from small financial institutions around the US, most with no previous relationship, using internet deposit listing services $3^{3}$ The new deposits were almost all term deposits paying above-market interest rates and structured to fall just under the FDIC insurance limit.

We then use a mix of public data and confidential supervisory data to show that our findings generalize to other US banks. We identify over 2,000 other banks that were subject to regulatory actions similar to the one faced by this studied bank. We find that banks facing such actions substitute funding away from brokered deposits and time deposits over $\$ 250,000$, but increase their reliance on listing service deposits and time deposits below $\$ 250,000$. Banks especially increase reliance on term deposits with balances above $\$ 100,000$ but below $\$ 250,000$, the range in which term deposits structured to fall just under the insurance limit would be. These results suggest our findings from the detailed micro data generalize to US banks facing enforcement actions.

Abstracting from the specifics of our bank, the run-in phenomenon we document has implications for the moral hazard arising from deposit insurance. On one hand, the run-in we document may be a beneficial phenomenon reflecting the fact that deposit insurance improves funding stability, allowing illiquid but solvent institutions to maintain sufficient private funding to avoid failure. On the other hand, our finding may reflect moral hazard arising from deposit insurance, allowing banks to choose socially inefficiently high levels of risk (while transferring much of this risk to the government). Because the run-in allows banks to shift credit risk from depositors to the government as they approach failure, depositors will not, in aggregate, demand appropriate risk premia. This in turn may incentivize the bank to make inefficiently risky loans. This run-in is a previously undocumented mechanism

\footnotetext{
${ }^{3}$ Listing services are firms which provide potential depositors with a list of deposit rates (one for each participating bank) for a number of standard deposit products, often sorted from the highest rate to the lowest and displayed on a website. For supervisory purposes, being classified as a listing service need not imply that one is a third-party deposit placement service, though some deposits may fall in both categories. For the sake of clarity we therefore use the terms "placed deposit" and "listing service deposit" as mutually exclusive terms, unless otherwise noted; if a deposit could be considered both, we code it as a placed deposit. For more detail on the supervisory definition and treatment of listed, placed, and brokered deposits, see FDIC's "Frequently Asked Questions on Identifying, Accepting and Reporting Brokered Deposits."
} 
by which deposit insurance weakens depositor discipline. Our results therefore emphasize the importance of supervisory discipline for financial stability $4_{4}^{4}$ Our findings on inflows also show the importance of assessing net and gross flows of funds to evaluate new liquidity regulations. Several prominent scholars have recently highlighted the dearth of academic research on new liquidity rules, in spite of liquidity concerns in the last financial crisis (Diamond and Kashyap (2016), Allen and Gale (2017)). We use our unique deposit-level data to assess these rules by considering net as well as gross outflows, the latter of which requires account-level data. We also directly compare our observed deposit run-off to the rates assumed in liquidity regulations. We find that, while the bank experienced lower rates of run-off than LCR would forecast, NSFR run-off rates (as currently drafted) are lower than what the bank experienced, especially during periods of extreme stress.

Our paper contributes to the existing literature in a number of ways. Much of the empirical literature on bank runs employs aggregate data. This literature in general finds that banks with worse fundamentals experience greater deposit withdrawals in a crisis (Gorton (1988); Saunders and Wilson (1996); Calomiris and Mason (1997)), and that large amounts of uninsured deposits can lead to unstable banks (Egan, Hortaçsu, and Matvos (2017)). A small set of papers examines responses of individual deposit(or)s to bank runs. These papers either use snapshots of data (Davenport and McDill (2006)) or data from banks in other countries, such as India (Iyer and Puri (2012); Iyer, Puri, and Ryan (2016)); Denmark (Iyer, Jensen, Johannesen, and Sheridan (2016)); and Switzerland (Brown, Guin, and Morkoetter (2014)). The theoretical model of Egan et al. (2017) provides a framework in which to understand our results. For example, their model predicts that uninsured depositors flee distressed banks, distressed banks pay higher rates to attract depositors, and insured depositors respond little or even flow into distressed banks - all of which we document empirically. Whether or not the inflows we find are socially beneficial is related to the causes of bank funding instability, the rationale for deposit insurance, and the literature on panic- versus fundamentals-driven bank runs (Diamond and Dybvig (1983), Jacklin and Bhattacharya (1988), Gorton (1988), Saunders and Wilson (1996), Calomiris and Mason (1997)). To the best of our knowledge, ours is the first paper to use continuous, daily, account-level depositor data for a failed bank in the US to systematically show the importance of deposit inflows in a failing bank occurring simultaneously with large deposit outflows. Our data covers a period in time when temporary deposit insurance measures such as TAG came into effect. As such, we are able

\footnotetext{
${ }^{4}$ Lacking reliable data on the asset side of our bank, we cannot assess the extent to which the run-in affected this particular banks lending behavior; the lending behavior of failing banks is left to future studies.
} 
to add to the literature by examining the effectiveness of both regular deposit insurance measures as well as temporary deposit insurance measures on which regulators worldwide have put much faith. We are also able to provide evidence on the stability of accounts based on their deposit product type, length of depositor relationship, and ownership structure. Additionally we throw light on new, post-crisis rules such as LCR and NSFR. Finally, we provide important new evidence of substantial deposit inflows in times of stress, raising significant questions about the effectiveness of depositor discipline on bank behavior. We are able to generalize the results on deposit inflows across a large sample of US banks that were subject to regulatory action. This is an important new result that has implications for future work on deposit stability by both academicians and regulators.

The remainder of the paper is organized as follows: Section 2 provides a brief history of the bank to highlight our key findings and provide context for later analysis. Then, Section 3 presents regression results on the drivers of deposit liquidation; Section 4 presents results on inflows of new depositors; and Section 5 generalizes our qualitative findings to all US banks. Section 6 documents our assessment of the LCR and NSFR rules in relation to the bank. Section 7 concludes.

\section{Data Description and Background}

We construct our dataset from data collected by the FDIC shortly after the bank's failure, building daily account balances for each deposit account. We associate accounts with their primary owner and his or her relevant characteristics. We are able to reliably construct account-level daily deposit balances from early 2006 until the bank's failure. We observe all account transactions over this period, including a granular description of the transaction and the dollar amount. We checked our constructed account balances against Call Reports on total deposits and deposits by account category, and deposits by branch against the FDIC Summary of Deposits data.5 General summary statistics about these bank accounts are shown in Table 1 .

Until mid-2007, this bank appeared relatively healthy. The bank had approximately $\$ 2$ billion in assets and primarily made residential real estate loans at this point in its life, but it also offered wealth management services. While the bank employed Federal Home Loan Bank advances (FHLBs) as funding sources, we find no evidence that it took discount

\footnotetext{
${ }^{5}$ We also, for example, checked individual accounts to ensure that accounts had zero balance before account opening and after closing, which ensures no transactions were missed.
} 
window loans or Troubled Asset Relief Program (TARP) funds. The bank sourced deposits from physical branches as well as internet depositors with a particular focus on savings accounts. The balances in accounts with some uninsured balances, both transaction and term deposits 6 , were steadily rising (see Figure 1).

By mid-2007, there were signs of the growing financial-system-wide stress at this bank. Between this time and August 2008, there was net run-off in uninsured balances. Figure 1 shows that this was particularly rapid among uninsured term deposits. While less than $40 \%$ of uninsured transaction balances ran off during the period, over $50 \%$ of uninsured term deposit balances did so; this is the first indication of our finding that term depositors are more risk sensitive. There was comparatively little change in insured deposits. While this period excludes the worst of the financial crisis, stress was building in the financial sector — Bear Stearns and IndyMac failed, Northern Rock experienced a run, and some investment funds had frozen withdrawals. Thus, it is not surprising that depositors, particularly sophisticated depositors, began to react. During this time period, the bank significantly curtailed its residential lending activities. Thereafter and up until failure, the bank continued to make commercial and personal loans, along with a small number of residential mortgage products.

Fall of 2008 saw severe credit and liquidity risks realized across the financial system as well as significant changes in financial policy. The most important policy change for our purpose was the increase in the FDIC's deposit insurance limit from $\$ 100,000$ to $\$ 250,000$ effective October 3, 2008:7 Additionally, the FDIC's TAG program became effective on October 14, 2008, temporarily providing unlimited deposit insurance for negotiable order of withdrawal (NOW) accounts, non-interest-bearing demand deposit accounts, and interest on lawyer trust accounts (IOLTAs), which cover all categories of checking accounts at this bank. The change in deposit insurance is evident in Figure 1, where uninsured deposits drop and insured deposits jump between the Pre-Crisis and Post-Crisis periods denoted with grey bars. Much of the sudden change in balances by insurance status is mechanical, as deposit accounts between $\$ 100,000$ and $\$ 250,000$ suddenly became insured. Much of the remaining change among transaction accounts reflects the almost simultaneous application of TAG guarantees. In contrast, changes in term deposit balances are partly driven by the

\footnotetext{
${ }^{6}$ Throughout this paper, we use the phrase "transaction account" to refer to all non-maturity accounts, namely, both checking and savings accounts. We acknowledge that the phrase "transaction account" has a more precise meaning in certain contexts, such as in the Federal Reserve's Regulation D. Additionally, we use "term deposit" and "certificate of deposit" ("CD") as synonyms. We classify accounts as insured or uninsured using an approximation of the deposit insurance process, aggregating deposit accounts based on their owners and ownership categories before applying the deposit insurance limit for each category.

${ }^{7}$ Initially, this increase was through the end of 2010, but it was made permanent by the Dodd Frank Act.
} 
bank's rapid acquisition of placed deposits, as shown in Figure 2 and discussed at greater length below. Further supporting the notion that term depositors at the bank are more sophisticated and risk-sensitive, uninsured term balances never increase substantially after October 2008.

The inflow of uninsured transaction deposits suggests that the time immediately after the financial crisis was one of limited stress at this bank. The acute system-wide stress of the crisis had receded and the bank's health had not yet significantly deteriorated 8 Then, about a year before the bank's failure, its primary federal regulator took its first publicly announced action to address the declining health of the bank through a Cease and Desist (C\&D) order $9^{9}$ The C\&D order cited a variety of issues at the bank including insufficient capital and poor board and management oversight, and it was made public immediately, appearing in the local press within a couple of business days. It was described by a banking analyst quoted in the local press as unusually harsh and indicative of high supervisory concern about the bank. Reports in the local press also remarked on the bank's poor health as revealed by its financial ratios in a recent public regulatory report 10 As can be seen in Figure 1, there is an increase in aggregate run-off for transaction accounts - both insured and uninsured unsurprisingly given the negative attention on the bank. As noted above, there were few uninsured term deposits left at the bank, although the few that remained still responded to the news.

Finally, three to four months before the bank failed, the banks' public regulatory filings (including amendments to previous filings) began showing the bank to be "significantly undercapitalized" and, within weeks, to be "critically undercapitalized." The term "critically undercapitalized" is defined by law as the lowest of five ranges for bank capitalization ratios. Banks are considered critically undercapitalized if their leverage ratio falls below $2 \%$; nearly insolvent in book value terms. Importantly, Prompt Correction Action (PCA) guidelines generally require federal regulators to place a bank into receivership or conservatorship (i.e., fail the bank) within 90 days of it becoming critically undercapitalized ${ }^{11}$ Depositors would

\footnotetext{
${ }^{8}$ Acharya and Mora (2015) document a similar inflow of deposits into the banking system after government actions in late 2008, suggesting the actions reaffirmed markets' confidence in the financial safety net and thus the safety of the financial system (see also Pennacchi (2006), Gatev and Strahan (2006)).

${ }^{9}$ The bank had previously been subject to a non-public memorandum of understanding (MOU) as well as a later troubled condition letter (TCL). These were intended to address many of the same problems which led to the bank's demise. Such confidential, informal enforcement actions are a common element of regulators' response to ailing bank health in earlier stages, when failure is relatively unlikely.

${ }^{10}$ We are unable to confirm the exact date of the regulatory report's release due to changes in the regulatory landscape following the financial crisis.

${ }^{11}$ See 12 U.S.C. $§ 1831$ o for more detail.
} 
expect the bank to fail soon, and uninsured deposit run-off accelerated substantially, as shown in the far right of the top panel of Figure 1.

Ultimately, the bank failed, and its primary federal regulator concluded that its failure was a result of heavy credit losses on the loan portfolio, especially adjustable rate mortgages. The resolution of the bank cost the FDIC approximately $10 \%$ of the bank's assets. For context, of the 54 banks with assets between $\$ 1$ and $\$ 10$ billion which failed 12 between 20072014, the average cost was $18 \%$ of bank assets with a right skew, placing this bank's losses in the middle third of the loss rate distribution.

\subsection{Defining Time Periods of Special Relevance}

For the purpose of our empirical analysis, we separately analyze depositor behavior in each of four windows of time available to us, described below. We identified these time periods using the bank's data and macroeconomic events in order to conduct our tests. In reverse chronological order, the time periods are:

- Formal Enforcement Action. This is a period of significant bank-specific distress and represents the primary time period of interest. This period begins with the C\&D order (a formal enforcement action) and ends with the failure of the bank. Unlike earlier periods, the stress arose from bank-specific adverse information, rather than from system-wide anxiety. This is generally abbreviated as the Formal period.

- Post-Crisis. The Post-Crisis period begins in December 2008, shortly after the government's emergency actions in fall 2008, and runs until the end of May 2009. The Post-Crisis period was a period of considerable distress across the financial system. Unlike in the Formal period, though, there were not significant revelations of bank-specific trouble. As such, the Post-Crisis period allows us to compare depositor behavior in response to market-wide stress. We exclude a few months in the fall of 2008 to avoid the confounding effects of emergency actions by the US government, as well as markets' expectations related to those actions.

- Pre-Crisis. The next time period we focus on is the year-long period before the financial crisis ending just before September 2008. As discussed above, uninsured deposits began running off during this period, particularly uninsured term deposits.

\footnotetext{
${ }^{12}$ We exclude open bank assistance (OBA) from our definition of failure in computing this statistic.
} 
- Placebo. We utilize a period of time in 2006 as a placebo period, establishing baseline depositor behavior when neither the bank nor the financial system were perceived to be especially troubled.

\section{Analysis of Deposit Run-Off}

This section presents an analysis using several regression models. We regress a dummy indicating whether the account liquidates on a variety of account and depositor characteristics in the context of Cox proportional hazard, linear probability (LPM), and probit models. Because the liquidation behavior of term deposits is quite different from that of transaction deposits, we run regressions separately on the two categories. For both term and transaction deposits, we run separate regressions for each of the four time periods described above: Placebo, Pre-Crisis, Post-Crisis, and Formal Enforcement Action.

All variables used in the regressions are defined in Table 2, with one other consideration related to TAG and Dodd Frank Act (DFA) deposit guarantees. In regressions estimated on the Placebo and Pre-Crisis periods, we replace the Covered by TAG/DFA dummy with a dummy variable which is equal to 1 if the account is a checking account and over the FDIC limit as of the start of the regression period. In those regressions, the replacement dummy variable is used to establish baseline behavior for large checking accounts, which is the same set of accounts covered by TAG subsequent to the crisis. Then, in the Formal period, we replace the Covered by TAG/DFA dummy with a Covered by DFA dummy. TAG ends and DFA guarantees begin midway through the Formal period, with the ultimate effect that NOW accounts are no longer covered by unlimited insurance. Given that TAG's expiration was known in advance, we may expect depositors in large NOW accounts to liquidate balances prior to the scheduled end of their deposit guarantees. This would generate a positive relationship between NOW status and liquidation at the same time that non-interest checking and IOLTA accounts (both still covered by DFA) may show a negative relationship. Thus, we only mark accounts covered by the DFA guarantees (but not TAG) with 1 for this dummy in the Formal period.

In the discussion of the results, we generally compare the Cox model results across different time periods. The Cox results are expressed as hazard ratios from a panel of accounts, meaning that they can be directly compared in spite of the fact that the time periods of the regressions are of different length; this is not true of the LPM and probit results, as they are run as cross sections and simply consider the probability of ever liquidating during the time 
period. We include dummies for the branch with which the bank associated each account, though we do not report their coefficients. Regressions here explain the rate of account liquidation ${ }^{13}$ as a function of deposit(or) characteristics; for a quantitative discussion of run-off rates, see Section 6 and its analysis of liquidity regulation.

\subsection{Drivers of Transaction Deposit Run-Off}

Focusing first on transaction deposits, Tables 3, 4, 5, and 6 present the regression estimates for each of the four time periods.

The Placebo period in 2006 (Table 3) establishes a baseline for "normal" depositor behavior with little financial stress. First, we find that the Uninsured dummy is statistically significant and positive, implying uninsured accounts liquidate at a rate about $14 \%$ faster than the baseline hazard, meaning insured deposits are more stable than uninsured deposits. Second, the interaction of the Uninsured dummy with the Checking dummy is not statistically different from zero, showing that uninsured checking accounts liquidate at the same rate as other uninsured accounts in normal times. This is a useful finding as it serves as a baseline against which to assess the impacts of TAG; during and after the crisis, this set of accounts was covered by the temporary, unlimited FDIC insurance provided by TAG. Next, the coefficient on checking is negative and significant, with depositors liquidating checking accounts at only a little more than half the baseline hazard rate, making checking accounts a relatively stable funding source. Fourth, we also show that accounts which are receiving direct deposits roughly every two weeks (indicative of direct-deposited paychecks or other regular transactions) are also less likely to liquidate, doing so at $65 \%$ of the baseline rate, as indicated by the negative and significant Direct Deposit dummy. Finally, the Trust dummy is insignificant, meaning that accounts held by trusts liquidate at about the same rate as the baseline hazard.

We also control for other account and depositor characteristics. Because there is relatively little variation across time periods in our coefficient estimates for these additional controls, we will discuss them mainly with respect to the Placebo period. For instance, depositors with a longer relationship with the bank are generally more stable as shown by the negative and significant coefficient on $\log (\mathrm{Age})$, though the coefficients are only significant in the Placebo and Formal periods. The rate at which depositors conduct transactions has a significant,

\footnotetext{
${ }^{13}$ As stated in Table 2, liquidation refers to withdrawing more than $50 \%$ of deposits as of the start of the period and then remaining that low for 61 days or longer. Results are robust to other thresholds of $75 \%$, $90 \%$, and $95 \%$.
} 
non-linear relationship with liquidation behavior, as both Prior Transactions coefficients are significant but with opposite signs. Accounts with very infrequent transactions (unaware or inactive depositors) and accounts with very frequent transactions (operationally important accounts, from the depositors' perspective) are less likely to liquidate than the baseline hazard. Accounts in the middle, with moderate usage, are more likely to liquidate than the baseline. While there are statistically significant differences in this basic result across time periods, the differences are economically insignificant. Finally, transaction accounts marked by the Institutional dummy are not significantly more or less likely to liquidate than the baseline account in all periods.

Moving to the Pre-Crisis period in Table 4, we see that little changes. The coefficient estimates for the Uninsured dummy are similar to their estimates from the Placebo period, though they are less consistently significant. The interaction of Checking and Uninsured remains statistically insignificant, and checking accounts and accounts receiving regular direct deposits remain roughly as stable (relative to the baseline hazard rate) compared to the Placebo period. The coefficient on trust accounts remains insignificant. Importantly, column 4 of Table 4 shows only the Prior Transactions coefficients are statistically different from their Placebo period counterparts, although the sign and statistical significance remain unchanged. The finding of similarities between the Placebo and Pre-Crisis periods is generally consistent with the historical discussion above, where transaction deposits did not much react to building financial weaknesses before the peak of the crisis.

Table 5 presents results for the Post-Crisis period. The Uninsured dummy is not statistically different from its earlier value (see column 4), but the point estimate is much larger: such accounts liquidate at a $44 \%$ higher rate than other accounts at the time. Similarly, the Covered by TAG/DFA dummy, formerly the interaction of Checking and Uninsured dummies before the advent of TAG, shows that such accounts liquidate less often. Although only the LPM coefficient estimate is statistically different from zero, the Cox model estimates TAGcovered accounts liquidate at a 30\% lower rate than the baseline hazard, and column 4 shows this estimate to be statistically different from the Placebo period. Table 5 also shows that checking accounts remain more stable than non-checking transaction accounts (i.e., savings accounts), liquidating about $30 \%$ less often, but the coefficient on the Checking dummy is statistically smaller than in the Placebo period. Accounts receiving bi-weekly direct deposits were previously less likely to liquidate than other accounts, and the impact is even stronger in the Post-Crisis period than the Placebo, as shown by the statistically significantly larger magnitude of the coefficient on Direct Deposit. The impact of prior transactions is statisti- 
cally (but not economically) significantly different from the Placebo period. Unlike in prior periods, the Trust dummy is significantly negative - trust accounts are stickier than other accounts in the period, running off about $26 \%$ slower.

Finally, Table 6 presents results for the Formal period. The impact of FDIC insurance is statistically stronger than in the Placebo period: uninsured accounts now liquidate at a rate $92 \%$ faster than other accounts according to the Uninsured dummy. Accounts covered by DFA guarantees liquidate about $15 \%$ slower than other accounts. However, the estimates are not significant across all specifications, and the difference relative to the Placebo period coefficient on Checking $\times$ Uninsured is not statistically significant. Table 6 also shows that checking accounts; accounts receiving direct deposits every other week; and accounts held by depositors with longer relationships with the bank continue to be statistically significantly stickier than other accounts. While checking accounts remain less likely to liquidate than other accounts in the Formal period (doing so about 20\% slower), the impact is statistically smaller than the corresponding estimate in the Placebo period; checking accounts remain sticky following bank-specific bad news, but less so than in response to market-wide stress. In contrast, the impact of the length of depositor relationships is stronger in the Formal period than in the Placebo period; such accounts are more sticky according to the negative $\log ($ Age) dummy. There is no such change for the Direct Deposit dummy. Trust accounts reverse their behavior from the Post-Crisis period and run off $17 \%$ faster than the baseline rate as shown by the Trust dummy.

These results have several important implications. First, we provide clear evidence that funds covered by deposit insurance are more stable, particularly in periods of stress. More generally, the large impacts in periods of stress demonstrate that depositors were aware of the bank's declining health and the limit of deposit insurance. For outflows, absent the gross run-in we analyze in the next section, this would suggest active depositor discipline. Second, in the Post-Crisis period, when TAG was in effect, the point estimates for Uninsured and Covered by TAG/DFA are statistically indistinguishable. The point estimates in the first two rows of Table 5 are similar in size, and a $t$-test of differences in the magnitudes of the coefficients between TAG and regular deposit insurance fails to reject the null of no difference with a $p$-value of 0.94 , indicating that the magnitude of the effect of TAG is the same as that of regular deposit insurance. Given that TAG was new and unconventional, the program and its operational details would have been unfamiliar to depositors; the magnitude of the impact we estimate bodes well for the effectiveness of such programs. By contrast, the impact of DFA guarantees in the Formal period is weaker. That said, there are relatively 
few accounts covered by DFA guarantees which were over the regular FDIC limit, so the coefficients are estimated with less precision than in earlier periods. Third, our finding that checking accounts and accounts receiving regular direct deposits are relatively stable in all environments supports assumptions made in rules such as the LCR and NSFR: to be considered the most stable form of funding for LCR purposes, deposit accounts must be fully insured retail deposits and either 1) a checking account or 2) held by a depositor with other relationships with the bank (such as loans, other accounts, bill payment services, etc.; Basel Committee (2013)).14 Finally, our finding on trust accounts suggests that such depositors are more sophisticated. Trusts are useful primarily to help wealthy individuals to protect their wealth, such that the average trust depositor is likely both wealthier and more financially savvy than the average depositor. Trust depositors should thus be more able to determine the solvency of the bank, a fact which could generate the observed behavior: they are less likely than others to flee in periods of general distress (Post-Crisis) when the bank itself is not near failure, but more likely to do so as the bank approaches failure in the Formal period.

\subsection{Drivers of Term Deposit Run-Off}

Next, we conduct a parallel analysis of run-off in term deposits. Table 7 presents results for the Placebo period regressions. First, the Uninsured dummy is statistically insignificant, meaning that uninsured term deposits do not liquidate more than insured accounts, probably because bank solvency was not a concern. Next, as we saw for transaction deposits, the effect of depositor relationship age as indicated by the $\log (\mathrm{Age})$ dummy is negative and, in some specifications, significant.15 Likely due to relationship depth, such accounts are more stable. Third, the further a term deposit is from its maturity date, the less likely it is to liquidate. Mechanically, this reflects the fact that few term deposits withdraw before maturity, especially in the Placebo period. Fourth, placed deposits (often thought of as "hot money," deposits without attachment to the bank and seeking high rates) liquidate three times as fast as other accounts as shown by the Placed dummy, and the impact is statistically significant. There are few institutional deposits at the bank in the Placebo period, but they appear to liquidate slightly more often than the baseline. Finally, trust deposits, as indicated by the Trust dummy, are less likely to liquidate than other accounts.

\footnotetext{
${ }^{14}$ Note that our definition of "checking account" is synonymous with the definition of "transaction account" in Federal Reserve Regulation D.

${ }^{15}$ Note that we treat the age of placed deposits differently, as discussed in Table 2
} 
Table 8 shows comparable results for the Pre-Crisis period. The Uninsured dummy is now statistically different from zero and its Placebo period value. Uninsured term deposits run-off at a rate about $17 \%$ faster than insured deposits, consistent with our finding from Section 2 that uninsured term deposits began running off during this period. Similarly, supportive of our finding from Section 2 that term deposits began running off sooner than transaction deposits, the impact of insurance in this period is larger than the corresponding estimate for transaction deposits. The stabilizing impact of depositor relationship age is stronger relative to the Placebo period (as seen in the $\log (\mathrm{Age})$ coefficient) and the impact of time to maturity is attenuated (as shown by the Log(Days to Maturity) coefficient), though both are statistically significant; the latter likely reflects the fact that there are more early liquidations than in the Placebo period. The table also shows that placed deposits continue to liquidate three times as fast as other accounts. Finally, trust accounts are no longer more stable than other term deposit accounts, with the Trust dummy becoming insignificant.

Table 9 shows responses in the Post-Crisis period. Point estimates for the impact of FDIC insurance are substantially higher than in earlier periods - uninsured accounts liquidate $64 \%$ faster than other accounts - and statistically different from the Placebo period. The results also show that placed deposits, which we expect would be particularly risk-sensitive, run off very rapidly, with the coefficient on the Placed dummy showing liquidations at 5.6 times the rate of the baseline runoff. The negative coefficients on the length of depositor relationship and time to maturity continue to indicate that longer relationships or times to maturity are stabilizing features. Institutional and trust accounts are not statistically significant, though their coefficient point estimates differ statistically from their Placebo period values.

Finally, Table 10 shows estimates for the Formal period. The FDIC insurance dummy remains large, significantly different from zero, statistically larger than in the Placebo period, and close to the point estimate from the Post-Crisis period; uninsured term deposits now run off $66 \%$ faster. The effect of the $\log ($ Age $)$ variable remains negative, but the effect is attenuated, and it is significant only in some specifications. Term deposits further from maturity are still less likely to liquidate, as seen in the negative Log(Days to Maturity) coefficient. Like trust transaction accounts in the Formal period, the Trust dummy demonstrates trust term accounts are more likely to liquidate. Finally, the results show a large response from wholesale accounts. Institutional deposits, both faxed/listed and, to a lesser extent, other institutional deposits, are more likely to liquidate given the two positive and significant Institutional dummies. However, many such deposits entered after the start of the Formal period, such that they are not included in these regressions. The Placed deposits dummy, 
on the other hand, attests that such deposits run off at a rate 14 times faster than other term deposit accounts, an high response relative to other periods and deposits, showing the high risk sensitivity of these wholesale deposits.

These results provide several significant insights. First and most obviously, the results for term deposits again confirm the stabilizing impact of deposit insurance. Second, taking the magnitude of the impact of insurance in each period as a reflection of term depositors' bank solvency concerns, our results also confirm that term deposits were more risk sensitive and ran off earlier than transaction deposits (a finding suggested by the discussion of Section 2 and figures referenced therein). Additionally, we show that placed deposits exhibit a high churn rate in all periods, but they respond even stronger under stress; this supports the view that placed deposits are hot money. As in the transaction deposit regressions, we find that longer depositor relationships help stabilize bank funding, and the strong response of trust depositors in the Formal period points to depositor sophistication.

Our finding that uninsured term deposits ran off earlier than transaction deposits may, at first, be surprising. While banking practitioners generally understand this point, economist intuition here is motivated by theoretical models of bank runs, which emphasize the role of deposit demandability. We suggest two reasons why term deposits are relatively unstable, in spite of their lack of demandability. First, term depositors at this bank, particularly uninsured term depositors, tend to be more sophisticated. A greater share of term depositors than transaction depositors are corporate entities (especially depository institutions), and these corporate entities may manage their assets more carefully. Second, the decision to open or renew a term deposit is inherently more forward-looking than decisions regarding transaction accounts because of term deposits' early withdrawal fees, and depositors may thus be more risk sensitive 16

\footnotetext{
${ }^{16}$ This rationale may be behavioral; although the bank had a schedule of early termination fees, term depositors generally did not pay an early withdrawal fee beyond forfeiting interest earned, and sometimes less than that. Over our sample period, a few dozen early term deposit breakages resulted in penalties which exceeded earned interest by as much as $2 \%$ of the principal balance (usually $1 \%$ or less), but most of these penalties were reversed by the bank and credited back to the depositor. Thus, it would appear there were low monetary costs to early term deposit withdrawal. However, we do not know if all customers would have received such favorable terms if they withdrew early, and those able to acquire favorable terms are thus incentivized to withdraw early. The very low breakage rate supports the assertion term depositors behaved as though they were making the deposits for the entire term.
} 


\subsection{Account Liquidation and the Withdrawal of Insured Funds}

Having established the increased propensity of uninsured depositors to draw down their deposits, we now investigate whether such depositors tend to draw down either to the insurance limit or well below it.

Table 11 presents our results for withdrawals from transaction accounts ${ }^{17}$ Each row represents one of our four periods, and for each period we consider the set of accounts with balances above $\$ 2,000$ under insurance limit at the start of the period. The columns then show balances of these accounts at the end of the period, in six account-balance bins. Relative to the Placebo and Pre-Crisis period, depositors in the latter two periods, especially the Formal period, tend to draw down well below the limit: the largest groupings in the Formal period, relative to previous periods, are accounts with $\$ 1$ or less and those between $\$ 2000$ and $\$ 2000$ under half the insurance limit (\$2000 to $\$ 123000$, in this period) 18 , with far fewer accounts remaining above the deposit insurance limit than in other periods. Under stress, uninsured depositors tend to withdraw much more than required to achieve full insurance coverage, either drawing down to less than half of the insurance limit or liquidating all funds.

This finding has significant implications for financial stability, since even some insured funds are likely to flee banks in response to stress, and can serve to inform banking theory models (such as Davila and Goldstein (2016)) 19

\section{Analysis of Deposit Run-In}

The previous section focused on depositor run-off, which is traditionally the area of attention with respect to bank funding stability. In this section, we demonstrate that run-in is also important to funding stability, even in a bank publicly known to be at high risk of failure. After providing an overview of the run-in dynamics at the bank, we use a regression framework to establish the characteristics of new depositors; present time series evidence that this run-in was not solely driven by factors external to the bank; and provide evidence that the run-in was instead attracted by the combination of credible deposit insurance and

\footnotetext{
${ }^{17}$ We do not show a comparable table for term deposits because their behavior is simpler: generally, they remain with the bank in full or exit entirely.

${ }^{18} \$ 2000$ was chosen based on where we observed depositors bunching and based on how much interest they may accumulate.

${ }^{19}$ Iyer et al. (2016a) find similar behavior among uninsured Danish bank depositors: in response to bad news about the bank during the financial crisis, they tended to follow the heuristic of splitting accounts in half between two banks to achieve full insurance coverage.
} 
above-market rates. We complete the section with a discussion of the policy implications of this new finding.

In the last year of its life, the bank attracted new, insured deposits, about half of which arrived in the last 90 days before failure - when the bank was publicly known to be critically undercapitalized. Figure 3 shows that the inflows of insured term deposits from new depositors to the bank totaled about $\$ 400$ million, about a third of the bank's deposit base and roughly equal to the volume of fleeing deposits; because of these flows, the bank's total deposit balances declined little as the bank approached failure. Figure 2 shows term deposits by various wholesale funding categories in the bank over time. This figure reveals that the inflows represented a shift in deposit composition: as placed term deposits (and transaction accounts) fled the bank, they were replaced by institutional term deposits, attracted mostly through internet deposit listing services and held almost exclusively by small banks across the country. Finally, Table 1 provides additional detail. Reflecting the fact that the new deposits were structured to fall just under the insurance limit, only $0.6 \%$ of new deposit accounts in the Formal period were uninsured, down from $4.0 \%$ in the Placebo period. Relatedly, the share of term deposits in new deposits is increasing over time; in the Formal period, nearly $90 \%$ of new accounts were term deposits. Finally, $82 \%$ of new deposits in the Formal period came from institutional depositors (Listed, Faxed, and Other Institutional), up from $2.8 \%$ in the Placebo period.

\subsection{Characteristics of New Depositors}

Having shown that the bank saw substantial deposit inflows, especially late in life, we conduct a classification regression analysis to characterize the differences between new and extant depositors in each period. The dependent variable is a dummy variable equal to 1 if the depositor is new and 0 if the depositor is old, with the right hand side being a vector of account characteristics 20 A zero coefficient on an explanatory variable signifies that characteristic is equally distributed between new and old depositors, and a positive value means it is more common among new depositors than old.

Table 12 presents the results of these OLS regressions. The Uninsured dummy shows that uninsured accounts are consistently and significantly 5 to 8 percentage points less common among new depositors than existing depositors. The relative commonality of uninsured accounts remains constant through time because, while the proportion of extant accounts

\footnotetext{
${ }^{20}$ Throughout the paper, unless otherwise noted, a depositor is considered new in any given time period if they open an account within the period and have never previously appeared in the bank's deposit records.
} 
that are uninsured at the bank falls over time, so does the proportion of new depositors that are uninsured. Focusing on the effects of TAG, as shown by the TAG dummy, uninsured checking accounts arrive in relatively large numbers in the Placebo period. This trend reverses in the Pre-Crisis period with uninsured transaction accounts being rarer among new depositors. However, suggesting that TAG was effective, in the Post-Crisis and Formal periods, over-the-limit transaction accounts are equally prevalent among new and existing depositors. The Checking dummy shows that checking deposits are less prevalent among new depositors than existing depositors, and term deposits are more prevalent. This is consistent with the low run-off rates of checking accounts and higher run-off rates of term deposits. As checking accounts are less likely to liquidate, the extant population should have a higher proportion of checking customers than the new population. Trust accounts, as indicated by the Trust dummy, are also notably more common in the Post-Crisis and Formal period. Finally, we see significant variation in wholesale deposits. We observe that Placed deposits are less common among new depositors compared to old depositors in most periods, save the Post-Crisis period, when we saw the highest inflows of such deposits in Figure 2. Faxed and listing service deposits, while usually more common among new depositors than extant ones due to high turnover, are drastically more common in the Formal period compared to previous periods. A randomly selected listed or faxed deposit is 87 percentage points more likely to be a new depositor than an old one as seen by its respective coefficient, all else equal. Other institutional deposits are always more common amongst new depositors compared to old depositors, although due to their small starting number, the Pre-Crisis period sees their highest relative prevalence among new depositors.

\subsection{Drivers of Gross Depositor Run-In}

While the previous section illustrates the prevalence of certain depositor characteristics among extant and new depositors, it does not explain the overall prevalence of new depositors compared to old depositors. This section builds upon the last by analyzing the time series of new deposits as a share of total deposits. The left hand side of the regression is the proportion of deposits that are new as of that day, while the explanatory variables are time period dummies and macroeconomic controls. Among the time dummies, the omitted period is the Placebo period, with dummies for the remaining three periods - Pre-Crisis, Post-Crisis, and Formal - as well as dummies for the spans of time between those periods, plus a prior-to-the-placebo dummy, for a total of seven dummies.

Table 13 presents the regression estimates . Focusing first on the macroeconomic con- 
trols, we find coefficient estimates consistent with economic intuition. High stock market volatility, as represented by $\log (V I X) \sqrt{21}$, is positively associated with new deposit inflows, as depositors seek safe and liquid assets. Higher GDP growth and stock returns are also associated with higher deposit inflows, consistent with wealth effects. Other measures that might impact aggregate deposit flows, such as housing starts or the bank's growth profile, are not statistically significant drivers of new deposits. The time series of new depositors' share of deposits is also strongly persistent at the daily frequency, as shown by the positive and significant $\mathrm{AR}(1)$ term 22

Now consider the time period dummies in Table 13. Although many of the time dummies are significant in specification 1 , most become insignificant in specification 2 with the addition of macroeconomic variables. However, even after the inclusion of macroeconomic controls, two time dummies remain significant: Placebo to Pre-Crisis, and Formal. The span between the Placebo and Pre-Crisis periods was a time of deposit growth for the bank, and the dummy's significance likely reflects this fact. More interestingly, we show that the Formal period dummy remains significant and large in magnitude. Given our set of controls summarizing macroeconomic conditions, this suggests that the inflows are explained by bank-specific conditions.

In fact, Figure 4 suggests the bank-specific cause was the high deposit rates offered by the bank in the Formal period. The figure compares the rates the bank paid on newly issued 12month CDs, a common deposit product that is representative of the bank's product portfolio and relative market position, showing both the actual rate and its relative ranking along with market percentiles.23 The figure shows the bank paid relatively high deposit rates throughout its life. However, as deposits flowed in over the last year of its life, the bank consistently paid rates above the 95th percentile of the industry distribution, often approaching the top 1\%. Interestingly, the time period between the Placebo and Pre-Crisis periods, the other time dummy that remains significant, is also a period in which the bank consistently paid rates above the 95 th percentile. Our evidence of the distressed bank raising deposit rates to attract insured deposits is in line with predictions of Egan et al. (2017).

\footnotetext{
${ }^{21}$ VIX is logged as it tends to span orders of magnitude and percentage interpretations are more appropriate.

${ }^{22}$ Note that this is not a mechanical result of constructing the series with overlapping measurement periods, as we define "new depositors" at the daily frequency.

${ }^{23}$ Rather than taking the average deposit rate being paid on all 12-month CDs at each date, we construct the series as the 31-day centered moving average of rates offered on newly issued term deposits. In this way, the rate series better reflects the rate a hypothetical depositor would have faced had they approached the bank on that date, and there also are some days in which no new 12-month CDs are issued.
} 


\subsection{Policy Implications of Run-In}

Beyond the specifics of the studied bank, the run-in phenomenon we document has several important policy implications. First, it suggests that depositor discipline was ineffective in restraining bank risk-taking. While some depositors enforced discipline on the bank by leaving, and new depositors were able to demand somewhat higher rates, new depositors offset the disciplining effect by opening new accounts. This finding is important especially because the Basel framework considers market (in this context, depositor) discipline of banks to be the third of three "pillars" of financial stability, and our finding points to limited disciplining power (among others, Martinez-Peria and Schmukler (1999); Park and Peristiani (1998)). This supports the rationale behind increased regulatory scrutiny and discipline.

Second and closely related, our finding emphasizes the importance of studying gross deposit flows rather than net deposit flows in understanding the trade-off between bank stability and moral hazard arising from deposit insurance. By making depositors less sensitive to bank risk, deposit insurance stabilizes deposit funding; the run-in makes this effect stronger. The run-in phenomenon may also prevent the socially inefficient failure of illiquid but fundamentally solvent banks or provide time for orderly bank resolution. On the other hand, less risk sensitive depositors also are less effective in restraining bank risk-taking, making prudential supervision more crucial to financial stability.

Third, the large inflow of new deposits suggests that deposit rate restrictions placed on troubled banks are insufficient to prevent rapid insured deposit acquisition, certainly in a low rate environment. Motivated by the depositor discipline and moral hazard concerns above, US law and regulation prohibits less than well capitalized institutions from paying deposit rates more than 75 basis points above the national average deposit rate on deposits solicited nationally. The bank we study was subject to these restrictions during the Formal period, and yet was able to attract deposits equal to around a third of its deposit base. The top panel of Table 1 shows that the bank complied with the rate restrictions; the spread to the market average on new accounts in the Formal period was around 69 basis points 24 Because the bank was able to attract so many new deposits while under the restrictions, we conclude the rate restrictions were at best a minimally binding constraint on the bank's behavior.

\footnotetext{
${ }^{24}$ Note that the spreads reported in the table are relative to our computed national average rate rather than that defined by the FDIC. We calculate our own national average series using a method identical to that used for the FDIC series. We use our computed series as the official data do not cover our entire sample period, and we wish to keep series consistency across our sample. The source data underlying the official average data changes with vintage, and we have not been able to recover the vintages used to construct the FDIC series. As a result, our averages tend to differ slightly from the official data. Using the official data over the supported period gives the same qualitative conclusions.
} 
However, it remains unclear whether the rate caps would be more effective if short, riskless rates were substantially above zero; the fed funds rate was at the zero lower bound for the entire period in which the rate caps were in place for this bank. To the extent that the dispersion of deposit rates is reduced when average rates are low (as suggested in Figure 4), the 75bp cap on the deposit rate spread would be less binding while at the zero lower bound compared to periods when rates are above it.

The final reason that the shift in deposit composition matters to policymakers is that it transfers risk to the FDIC. In addition to fleeing insured deposits, about $\$ 150$ million of uninsured transaction deposits also left. Because the bank replaced these fleeing uninsured deposits with insured institutional term deposits, the share of the bank's deposits covered by insurance and the credit risk exposure of the FDIC increased as the bank approached failure.

\section{Generalization to Other Banks}

The unusually granular data for this bank allows us to identify changes in deposit composition as it approached failure, but we unfortunately have such data for only a single bank. When we initiated this project, we asked for data from a sample of 10 banks to be recovered and put on a secure server on which we could access the data. We then examined deposit data in each bank. Unfortunately, for many of the banks, the deposit data is incomplete. For some of the banks, the data between systems cannot be appropriately linked; for example, databases sometimes lack identifiers to link transactions (from one database, and necessary for calculating account balances) with deposit accounts (from another database, necessary for many permanent account characteristics) or customer systems (containing separate customer characteristics.) Other banks might keep only the most recent three months of detailed transaction history. Each bank has different storage and retention policies. Compounding these data challenges is the fact that the data contain large volumes of sensitive and personally identifiable information, such that access to the data is highly restricted, and uploading the data to secure IT environments with statistical analysis software is time-consuming. Due to the combination of these factors, it took well over a year for us to obtain access to data for a sample of just 10 failed banks, and after analyzing their data, we determined only the single bank we study had suitable deposit data. As reported earlier, for the bank we study, we are confident that the deposit data are complete by matching to the Call Reports, but this is not true for the other banks. Given these data constraints on micro data from failed 
banks, we use an alternative approach using a variety of other data sets available for a large set of banks. This section analyzes a combination of public and private regulatory data to demonstrate that our major findings generalize to other banks.

To generalize our results, we use Call Report data for all US banks to investigate whether banks that face a regulatory action see similar changes in deposit composition. In particular, we investigate the impact of "treatment" with a regulatory action on five funding measures. The five funding measures are the share of each bank's total deposit funding in the form of brokered deposits, listing service deposits, small term deposits (those under $\$ 100,000$ ), medium term deposits (those over $\$ 100,000$ but under $\$ 250,000$ ), and large term deposits (those over \$250,000) 25 Each series is regressed on a dummy ("treatment") variable for whether or not the bank was facing regulatory action similar to the studied bank, as well as a set of control variables. We define a bank to be facing regulatory action if it is under a formal enforcement action that includes capital-related provisions or if it is less than well capitalized ${ }^{26}$ without specific written permission from the regulator to continue taking brokered deposits, usually referred to as a brokered deposit waiver. Less than well capitalized institutions are forbidden from taking new brokered deposits or rolling over old ones unless they have a brokered deposit waiver. Note that any bank meeting our definition of regulatory treatment will also be subject to deposit rate restrictions. The treatment variable is defined using data from public Call Reports and confidential FDIC data, which provides the details of the enforcement actions and brokered deposit waivers. The advantage of this approach is that it gives us a large panel of banks - around 10,000 banks, of which 2,358 faced regulatory action.

The control variables are derived from Call Reports. Control variables are non-performing assets as share of assets, to capture bank health; one-year asset growth rate, to capture the growth and current risk profile of the bank; the natural logarithm of assets, to capture size; deposits as a share of assets, to capture the banks' reliance on deposits generally; and term deposits as a share of deposits, to capture their reliance on term deposits particularly ${ }^{27} \mathrm{We}$

\footnotetext{
${ }^{25}$ The average bank in our sample has $3.1 \%$ of its deposits classified as brokered, $1.6 \%$ as listed, $20.2 \%$ as small term deposits, $13.1 \%$ as medium term deposits, and $5.5 \%$ as large term deposits.

${ }^{26}$ See 12 U.S.C. $\$ 1831$ o for capital category definitions.

${ }^{27}$ We altered the raw Call Report data by correcting for apparent reporting errors and by winsorizing. Specifically, in a handful of bank-quarters, banks appear to have reported brokered deposits in dollars, inconsistent with the Call Report standard of thousands of dollars, requiring us to divide by 1000 . When funding shares calculated from Call Reports were a fraction of a percent above $100 \%$ or below $0 \%$, we assume this is due to rounding error, and we round to $100 \%$ or $0 \%$, respectively. Finally, we bounded one-year asset growth rates between $-50 \%$ and $100 \%$, affecting about $2 \%$ of bank-quarters, with large asset shifts usually due to new small banks growing rapidly in the first few quarters. Importantly, none of these changes materially
} 
use quarterly data for all US banks from 2000 to 2016, with 2,358 banks facing regulatory action and 9,158 not facing them at some point during this time. However, because we rely on the Call Report taxonomy of deposit accounts and because this taxonomy has changed through time, some regressions use shorter samples.28 Note that regressions also include bank and quarter fixed effects.

Finally, we conduct our analysis under three different model specifications. Two of the specifications are simple OLS models and differ only in the specification of the treatment dummy. In one, we have a single treatment dummy which is equal to one in any bankquarter where regulatory action was in place; in this case, the untreated ("control") group is all banks not contemporaneously under a regulatory action. In another, we use separate dummy variables for each quarter from four quarters before the imposition of treatment to four quarters after, plus an additional dummy for five or more quarters of continuous treatment; in this case, the control group is banks which will not face such action for at least the next four quarters. Finally, we estimate a third specification on propensity-scorematched banks. Banks' propensity to be treated is determined by a logistic regression using the same covariates as in the above regressions, plus contemporaneous term deposit size shares. Then, banks with similar propensity scores — where one was treated and the other was not - are compared after four quarters of continuous treatment to observe the effects of that treatment. The results are consistent across all specifications.

Table 14 shows the results of regressions with a single regulatory action dummy variable. Consistent with our earlier findings, banks under regulatory action reduce their reliance on brokered deposits while increasing listing service deposits. These two compositional shifts do not completely offset one another, but banks may also be seeking other classes of deposits. In addition, there is an increase in the reliance on term deposits below $\$ 100,000$ as well as between $\$ 100,000$ and $\$ 250,000$, with a decrease in deposits above $\$ 250,000$.

Table 15 and the accompanying Figure 5 demonstrate the time path of the effects of regulatory action on the same deposit categories. Relative to banks who are more than four quarters away from regulatory action, banks one to four quarters before an action have statistically significantly more brokered deposits. Following the application of such restrictions, these banks become much less likely to source such deposits, reflecting the

affects the point estimates of the treatment variable.

${ }^{28}$ Listing service deposits were not separately identified or reported on Call Reports before the first quarter of 2011, and data necessary to disaggregate term deposits by size is available beginning in 2010. This limited our listing service deposit sample to 559 treated and 7,020 untreated banks and our term deposit sample to 807 treated and 7,141 untreated banks. 
concurrent application of brokered deposit restrictions. The exact opposite pattern appears with listing service deposits, with banks prior to such events having fewer and those after having more. Presumably, this pattern reflects inflows of listing service deposits conceptually similar to those documented previously. Small time deposits are relatively more prevalent in banks in the last few quarters before regulatory action than in the control group, and the difference becomes even more stark after regulatory action. Medium time deposits make up a smaller share of funding at banks prior to regulatory action compared to the control group, but also become more common following regulatory action. Finally, large time deposits are equally as common among banks far from regulatory action as well as those within only a few quarters of action, but they become much less common among banks following regulatory action. Table 16 shows that our generalization results are robust to using a propensity-scorematched specification.

This analysis generalizes our earlier findings along several dimensions. These regressions consistently find that banks under regulatory action reduce reliance on brokered deposits (due to concurrently applied brokered deposit restrictions) and deposits above the insurance limit (reflecting the flight of uninsured depositors from the ailing bank). These regressions show that banks under regulatory action increase reliance on listing service deposits, much as the bank featured earlier in this paper did. Treated banks also increase reliance on term deposits under the insurance limit, and especially those between $\$ 100,000$ and $\$ 250,000$. Recall that the bank featured earlier in this paper structured most of its new term deposits during the Formal period to fall just under the insurance limit — within this range.

\section{Run-Off, Run-In, and Regulatory Liquidity Ratios}

As a final empirical exercise, we use our novel failed bank data as an opportunity to evaluate the deposit run-off rates assumed in the two post-crisis liquidity ratios, LCR and NSFR ${ }^{29}$ It is of independent interest to empirically assess new liquidity regulations; in fact, several scholars have recently bemoaned the dearth of independent academic research in this area (Diamond and Kashyap (2016), Allen and Gale (2017)). Our analysis highlights the importance of gross flows to understanding aggregate run-off rates. The rules' deposit run-off rates can be thought of as net rates. Most scholars focus on outflows; our paper contributes by showing

\footnotetext{
${ }^{29}$ The rules were initially proposed by the Basel Committee and are being implemented by country-level supervisory agencies. We focus on the US supervisory agencies' final LCR rule (Federal Register (2014)), as well as their proposed NSFR rule (Federal Register (2016)). The US agencies have not yet finalized the NSFR rule. Note that the results would be little changed if we used the Basel proposals instead.
} 
the importance of gross inflows in materially affecting overall deposit flows. We find that the deposit run-off rate assumptions in the LCR are higher than the run-off behavior we see in this bank, but that the proposed US NSFR rule assumes run-off rates lower than seen at our bank 30

Given the nature of our data, our analysis focuses solely on run-off rate assumptions for deposit products in the two liquidity ratios. Thus, we are not assessing other aspects of the rules, such as the liquidity of assets. We compute the rule-implied aggregate deposit run-off rate for the bank by categorizing all accounts into the relevant LCR/NSFR run-off categories and then taking the value-weighted average of the categories' assumed run-off rates.

We find an area of potential regulatory arbitrage in the rules related to operational deposits. Operational deposits are business deposits which are maintained at the bank as part of an arrangement in which the bank provides clearing, custodial, or cash management services, including accounts used for payroll. Operational deposit balances are assumed to be more stable and thus have a lower assumed run-off rate than non-operational business deposits. There are guidelines on how to determine the division of accounts and bank supervisors review banks methodologies, but banks have the incentive and some discretion to overstate the operational share of their business deposit balances so as to make their funding appear more stable 31 To reflect this incentive, we construct a range of rule-implied run-off rates; the bottom of the range reflects the assumption that all deposits which could be operational actually are, and the top of the range treats them as nonoperational.

Our analysis suggests that the LCR deposit run-off rates are about as high as the runoff we observe in stressed periods. The results are shown in top panel of Figure 6, where net declines in deposit balances (aggregate run-off) are represented with positive values and increases in deposit balances (aggregate run-in) are negative. At no point does the observed run-off exceed the maximum value of the LCR-consistent range, though it comes fairly close in 2008. In that period, for many allocations of business deposits between operational and non-operational categories, the bank's run-off would have exceeded the rules assumed rate.

In contrast, we find evidence that our bank experienced run-off exceeding the NSFR runoff rate (Figure 6, bottom panel), reflecting NSFR's design-intent to improve bank funding stability over more normal business conditions than the stress-focused LCR. Run-off exceeds the NSFR range both in the period of system-wide anxiety around the crisis and subsequent to the publication of bank-specific adverse information in the year before failure. In the

\footnotetext{
${ }^{30}$ We acknowledge that our quantitative results here should be interpreted with some caution: the bank we study would not be subject to the rules even if it still existed, as it was too small.

${ }^{31}$ These guidelines are enforced through detailed examiner enforcement and attention.
} 
former case, the observed runoff exceeds the rule-implied range regardless of the treatment of run-in. In the year the before failure, only the gross outflows would exceed the NSFR threshold.

\section{Conclusion}

In this paper we use a highly granular and unique dataset to identify important new findings related to deposit inflows and outflows in a failing bank. Our most important finding is that gross deposit inflows are of first order impact in failing banks' balance sheets, despite the banks' elevated default risk and supervisory actions meant to prevent costly and rapid deposit acquisition. This result strongly supports the notion that deposit insurance increases the willingness of depositors to fund banks, as it supports cheap lending to a highly leveraged firm. This mechanism may prevent the inefficient failure of solvent banks facing liquidity issues, potentially a positive outcome. On a more negative note, it may also reflect the other side of insurance - moral hazard. Finally, that the bank attracted these inflows through the comparatively new channel of internet listing services stands as a warning that technological innovation can open new avenues for moral hazard.

We identify a number of policy-relevant findings related to gross deposit outflows. Most importantly, we provide further evidence that deposit insurance improves funding stability. We also provide the first empirical evidence that temporary, crisis-era expansions of deposit insurance, such as FDIC's TAG, are as effective as ordinary deposit insurance. Many of our findings on outflows agree with the intuition already written into regulations, such as that checking accounts and accounts receiving regular direct deposits are more stable. Other findings may be somewhat less intuitive, such as the fact that, despite their lack of demandability, term deposits are more risk sensitive and unstable than demandable deposits. We then demonstrate that our main findings generalize to other banks by using a combination of public regulatory filings and confidential supervisory data. Finally, we illustrate the importance of understanding and measuring both outflows and inflows by demonstrating the

sensitivity of LCR and NSFR to assumptions on measurements of inflows. This exercise also provides evidence as to the realism of deposit run-off rates assumed in the rules. 


\section{References}

Acharya, Viral V., and Nada Mora (2015), "A Crisis of Banks as Liquidity Providers," Journal of Finance, Vol. 70(1), pp. 1-43.

Allen, Franklin, and Douglas Gale (2017), "How Should Bank Liquidity Be Regulated?" mimeo.

Basel Committee on Banking Supervision (2013), "Basel III: The Liquidity Coverage Ratio and Liquidity Risk Monitoring Tools," Bank for International Settlements, June 2013.

Brown, Martin, Benjamin Guin, and Stefan Morkoetter (2014), "Deposit Withdrawals from Distressed Commercial Banks," Univ. of St. Gallen, Working Paper on Finance 2013-19.

Calomiris, Charles W., and Joseph R. Mason (1997), "Contagion and Bank Failures during the Great Depression: The June 1932 Chicago Banking Panic," American Economic Review, Vol. $87(5)$, pp. 863883.

Davenport, Andrew Mitsunori, and Kathleen Marie McDill (2006), "The Depositor Behind the Discipline: A Micro-Level Case Study of Hamilton Bank," Journal of Financial Services Research, Vol. 30, pp. 93-109.

Davila, Eduardo, and Itay Goldstein (2016), "Optimal Deposit Insurance," mimeo.

Dewatripont, Mathias, and Jean Tirole (1994), "The Prudential Regulation of Banks," MIT Press.

Diamond, Douglas W., and Philip H. Dybvig (1983), "Bank Runs, Deposit Insurance, and Liquidity," Journal of Political Economy, Vol. 91(3), pp. 401-419.

Diamond, Douglas W., and Anil K. Kashyap (2016), "Liquidity Requirements, Liquidity Choice, and Financial Stability," in Handbook of Macroeconomics, Vol. 2, eds. John B. Taylor and Harald Uhlig, pp. 2263-2303.

Egan, Mark, Ali Hortaçsu, and Gregor Matvos (2017), "Deposit Competition and Financial Fragility: Evidence from the US Banking Sector," American Economic Review, Vol. 107(1), pp. 169-216.

Federal Register (2014), "Liquidity Coverage Ratio: Liquidity Risk Management Standards; Final Rule," Vol. 79(197), October 10, 2014, pp. 61440-61541.

- (2016), "Net Stable Funding Ratio: Liquidity Risk Management Standards and Disclosure Requirements; Proposed Rule," Vol. 81(105), June 1, 2016, pp. 35124-35183. 
Gatev, Evan, and Philip E. Strahan (2006), "Banks Advantage in Hedging Liquidity Risk: Theory and Evidence from the Commercial Paper Market," Journal of Finance, Vol. 61(2), pp. 867-892.

Gorton, Gary (1988), "Banking Panics and Business Cycles," Oxford Economic Papers, Vol. 40, pp. 751-81.

Iyer, Rajkamal, and Manju Puri (2012), "Understanding Bank Runs: The Importance of Depositor-Bank Relationships and Networks," American Economic Review, Vol. 102(4), pp. 1414-1445.

Iyer, Rajkamal, Thais Jensen, Niels Johannesen, and Adam Sheridan (2016a), "The Run for Safety: Financial Fragility and Deposit Insurance," mimeo.

Iyer, Rajkamal, Manju Puri, and Nicholas Ryan (2016b), "A Tale of Two Runs: Depositor Responses to Bank Solvency Risk," Journal of Finance, Vol. 71(6), pp. 2687-2726.

Jacklin, Charles T., and Sudipto Bhattacharya (1988), "Distinguishing Panics and Informationbased Runs: Welfare and Policy Implications," Journal of Political Economy, Vol. 96(3), pp. 568-592.

Martinez-Peria, Maria Soledad, and Sergio Schmukler (1999), "Do Depositors Punish Banks for "Bad" Behavior?: Market Discipline, Deposit Insurance, and Banking Crises," Journal of Finance, Vol. 56(3), pp. 1029-1051.

Park, Sangkyun, and Stavros Peristiani (1998), "Market Discipline by Thrift Depositors," Journal of Money, Credit, and Banking, Vol. 30(3), pp. 347-364.

Pennacchi, George (2006), "Deposit Insurance, Bank Regulation, and Financial System Risks," Journal of Monetary Economics, Vol. 53(1), pp. 1-30.

Saunders, Anthony, and Berry Wilson (1996), "Contagious Bank Runs: Evidence from the 1929-1933 Period," Journal of Financial Intermediation, Vol. 5(4), pp. 409-423. 
Table 1: Summary Statistics, by Period

(a) New Depositors

Placebo Pre-Crisis Post-Crisis Formal Failure

\begin{tabular}{lccccc} 
& $(1)$ & $(2)$ & $(3)$ & $(4)$ & $(5)$ \\
\hline Number of New Accounts & 2858 & 1872 & 813 & 2199 & - \\
New Depositors Per Day & 13.355 & 5.128 & 4.492 & 6.525 & - \\
Uninsured at Start of Account & 0.040 & 0.024 & 0.010 & 0.006 & - \\
Starting Balance & 28111 & 33482 & 66207 & 168262 & - \\
Term & 0.446 & 0.498 & 0.406 & 0.869 & - \\
Savings & 0.504 & 0.386 & 0.424 & 0.070 & - \\
Checking & 0.049 & 0.116 & 0.170 & 0.061 & - \\
Checking \& Uninsured & 0.009 & 0.006 & 0.005 & 0.000 & - \\
$\quad$ (TAG/DFA-covered accounts) & & & & & \\
Starting Interest Rate & 4.698 & 3.468 & 1.552 & 1.191 & - \\
Starting Interest Spread to Market & 2.883 & 1.919 & 0.877 & 0.693 & - \\
Institutional - Listed/Faxed & 0.000 & 0.007 & 0.032 & 0.752 & - \\
Institutional - Other & 0.028 & 0.222 & 0.225 & 0.066 & - \\
Placed & 0.001 & 0.029 & 0.181 & 0.009 & - \\
Trust & 0.037 & 0.031 & 0.082 & 0.037 & - \\
\hline
\end{tabular}

(b) Extant Depositors

\begin{tabular}{lccccc}
\hline Number of Accounts & 42257 & 46332 & 38927 & 31114 & 25847 \\
Uninsured at Start of Period & .064 & 0.084 & 0.011 & 0.022 & 0.016 \\
Starting Balance & 27865 & 27466 & 32057 & 44886 & 48642 \\
Term & 0.196 & 0.256 & 0.226 & 0.127 & 0.194 \\
Savings & 0.728 & 0.676 & 0.694 & 0.762 & 0.674 \\
Checking & 0.077 & 0.068 & 0.080 & 0.111 & 0.132 \\
Checking \& Uninsured & 0.006 & 0.007 & 0.004 & 0.004 & 0.004 \\
$\quad \rightarrow$ (TAG/DFA-covered accounts) & & & & & \\
Direct Deposit & 0.027 & 0.029 & 0.023 & 0.034 & 0.031 \\
Starting Interest Rate & 4.095 & 4.372 & 2.484 & 0.936 & 0.880 \\
Starting Interest Spread to Market & 2.979 & 3.090 & 1.763 & 0.740 & 0.665 \\
Institutional - Listed/Faxed & 0.000 & 0.000 & 0.001 & 0.003 & 0.083 \\
Institutional - Other & 0.014 & 0.016 & 0.028 & 0.050 & 0.068 \\
Placed & 0.013 & 0.016 & 0.047 & 0.039 & 0.008 \\
Trust & 0.015 & 0.017 & 0.017 & 0.023 & 0.028 \\
Age of Relationship in Years & 2.241 & 3.103 & 4.25 & 5.810 & 6.120 \\
Years Since Start of Previous Period & - & 1.25 & 1.25 & 1.78 & 0.92 \\
\hline Pan (a) Shows
\end{tabular}

Panel (a) shows summary statistics across all new depositors opening accounts in each of the four event periods. Depositors who already had an account at the bank at the beginning of each period are excluded. Panel (b) shows corresponding statistics for depositors who were extant at the bank, as of the beginning of each period. 


\section{Table 2: Variable Definitions}

\begin{tabular}{ll} 
Variable & Definition \\
\hline Liquidation & A dummy variable equal to 1 if a deposit account balance falls below $50 \%$ of the account \\
& balance as measured at the beginning of the regression period, and the balance stays that \\
& low or lower for at least 61 days, which includes the account closing. This dummy captures a \\
& generally accepted notion of account liquidation consistent with related studies (for example, \\
& Iyer and Puri $(2012))$. Results in this paper are robust to different thresholds of $75 \%, 90 \%$, \\
& and $95 \%$.
\end{tabular}

Uninsured A dummy variable equal to 1 if there are any uninsured balances in the account as of the start of the measurement period. Deposit insurance limits apply separately to different ownership types, so we account separately for individual, corporate, municipal, joint, IRA, employee benefit plans, revocable trust, and irrevocable trust ownership categories. An exact insurance determination can sometimes be difficult, as joint and trust accounts have complex ownership structures which are often incompletely documented, hence we construct this variable conservatively. Accounts we flag as insured have all funds insured. Accounts we flag as uninsured should have some uninsured funds in them, but it is possible that they are occasionally covered because of complex joint ownership. As a result, estimates in our regressions are lower bounds on the effects of being over the FDIC insurance limit.

Covered by A dummy variable equal to 1 if the accounts was covered by additional, temporary guarantee $T A G / D F A \quad$ schemes in the years after the financial crisis as of the start of the regression period; 0 otherwise. The two additional guarantee schemes were the Transaction Account Guarantee (TAG) program and guarantees from by the Dodd Frank Act (DFA). TAG, a sub-program of the FDIC's Temporary Liquidity Guarantee Program (TLGP), placed temporary but unlimited (in dollar terms) guarantees on products which comprise all categories of checking accounts at this bank. These guarantees were in force from October 14, 2008 until December 31, 2010. The DFA guarantees similarly provided unlimited insurance for non-interestbearing demand deposit accounts and IOLTA accounts, but not NOW accounts. The DFA guarantees were in force from December 31, 2010 until December 31, 2012.

Direct A dummy variable equal to 1 if the account is receiving an ACH deposit roughly every two Deposit $\quad$ weeks as of the start of the regression period; 0 otherwise, and always 0 for term deposits.

$\log (\mathrm{Age}) \quad$ The natural log of the years elapsed since the primary account holder first appears in the bank's deposit records, as of the start of the regression period. If an individual was a secondary depositor on an account before they became a primary account holder on another account, or closed an older account, we use the date at which the original account was opened. Relationship age serves as a measure of the depth of the depositor relationship. The age of the account is dated differently in the case of placed deposits; see placed deposits below for details.

$\log ($ Days to The natural log of the number of days until the maturity of the account, as of the start of Maturity) the regression period. This is defined only for term accounts.

This table defines the variables used in the regressions of Section 3. 
Table 2: Variable Definitions

\begin{abstract}
Variable Definition
Prior The proportion of days in the past year, as of the start of the measurement period, in Transactions which the account holder performed at least one transaction involving the account under study. A value of 0 thus implies no activity and 100 implies activity every day. We exclude transactions which are exogenous to the depositor such as monthly interest credits or fees. This serves as another measure of depositors' relationship depth. This variable is always 0 for term accounts.
\end{abstract}

Institutional- A dummy variable equal to 1 if the deposit is owned by a bank, savings association, credit Listed/Faxed union, financial corporate, municipality, or non-financial corporation, or if it is a "business" product type as marked in the bank's records; 0 otherwise. Additionally, the deposit must have been opened via an internet listing service or facsimile as identified by the bank's records. We group faxed deposits with listed because internal bank documentation, depositor behavior, and depositor types (namely, small depository institutions making up a large portion of these deposits towards the end of the bank's life) all indicate that the faxed deposits were almost exclusively gathered from depositors who saw the rates on listing services and then faxed their deposit request to the bank. This excludes third-party deposit placement services (such as deposit brokers) as we capture these entities with a separate dummy variable.

Institutional- A dummy variable exactly defined As Institutional - Listed/Faxed above, but we have no Other evidence that the deposits were received from a listing service or facsimile order.

Placed A dummy variable equal to 1 if the deposit was placed by a fiduciary or deposit broker instead of by an individual depositor; 0 otherwise and always 0 for transaction accounts. Many term deposits at the bank are not held by individuals but instead held by institutions acting as fiduciaries for others, and these fiduciaries do not consistently reveal the identity of the underlying holders of the account to the bank. These deposits reflect a less personal connection with the bank. For these accounts, the age of the account variable is dated to the start of the individual account, not the first relationship of the reported holder of the account, as the reported holder is only a fiduciary that may not make final renewal and withdrawal decisions. Note that we assume all placed deposits are insured, which is supported by internal FDIC analysis of several failed banks and the websites of the deposit placement services present at the studied bank, as they advertise that they structure their deposits so as to achieve full insurance coverage.

Trust A dummy variable equal to 1 if the account is held by a trust and 0 otherwise. This does include Payable on Death (POD) arrangements. Trust accounts require effort to establish, and they are a useful legal device more for wealthier or more complex depositors. As such, we expect accounts held in trust to represent more sophisticated end-depositors.

This table defines the variables used in the regressions of Section 3. 
Table 3: Who Withdraws? Placebo Period; Transaction Deposits

\begin{tabular}{lccc} 
& Cox P.H. & LPM & Probit \\
& $(1)$ & $(2)$ & $(3)$ \\
\hline Uninsured & $1.140^{* *}$ & $0.0300^{* *}$ & $0.0306^{* *}$ \\
& $(2.27)$ & $(2.21)$ & $(2.16)$ \\
Checking \& Uninsured & 1.164 & 0.0210 & 0.0317 \\
$\hookrightarrow$ Later Covered by TAG/DFA & $(1.07)$ & $(0.64)$ & $(0.91)$ \\
Checking & $0.526^{* * *}$ & $-0.137^{* * *}$ & $-0.123^{* * *}$ \\
& $(-11.01)$ & $(-11.99)$ & $(-13.71)$ \\
Direct Deposit & $0.648^{* * *}$ & $-0.104^{* * *}$ & $-0.0928^{* * *}$ \\
& $(-5.87)$ & $(-6.45)$ & $(-7.19)$ \\
Log(Age) & 0.989 & $-0.00757^{* * *}$ & $-0.00565^{* *}$ \\
& $(-1.00)$ & $(-2.73)$ & $(-2.09)$ \\
Prior Transactions & $1.071^{* * *}$ & $0.0145^{* * *}$ & $0.0148^{* * *}$ \\
& $(23.40)$ & $(22.71)$ & $(22.55)$ \\
Prior Transactions ${ }^{2}$ & $0.999^{* * *}$ & $-0.000186^{* * *}$ & $-0.000196^{* * *}$ \\
& $(-16.86)$ & $(-19.28)$ & $(-18.42)$ \\
Institutional - Any & 0.874 & -0.0203 & -0.0248 \\
& $(-1.17)$ & $(-0.81)$ & $(-1.02)$ \\
Trust & 0.966 & -0.00207 & -0.00429 \\
& $(-0.25)$ & $(-0.07)$ & $(-0.14)$ \\
Branch Controls & & & \\
$N$ & Yes & Yes & Yes \\
Log Likelihood & 6125877 & 33973 & 33973 \\
Model P-Value & -91348.3 & -19977.1 & -19220.4 \\
No. of Liquidations & $<0.001$ & $<0.001$ & $<0.001$ \\
\hline & 8920 & 8920 & 8920 \\
\hline
\end{tabular}

Estimates from Cox proportional hazard, linear probability, and probit models for the probability of account liquidation during the placebo period, well before the financial crisis. Liquidation is defined as withdrawing more than $50 \%$ of the account balance and remaining below that level for 61 days or more. Cox estimates are expressed as hazard ratios, LPM estimates are OLS coefficient estimates, and Probit estimates are marginal effects. T-statistics are in parentheses. Estimates significant at $1 \%$ are denoted with ${ }^{* * *}, 5 \%$ with ${ }^{* *}$, and $10 \%$ with *. 
Table 4: Who Withdraws? Pre-Crisis Period; Transaction Deposits

\begin{tabular}{|c|c|c|c|c|}
\hline & $\begin{array}{c}\text { Cox P.H. } \\
\text { (1) }\end{array}$ & $\begin{array}{c}L P M \\
(2)\end{array}$ & $\begin{array}{c}\text { Probit } \\
\text { (3) }\end{array}$ & $\begin{array}{l}\text { Difference vs. } \\
\text { Placebo } \\
\quad(4)\end{array}$ \\
\hline Uninsured & $\begin{array}{c}1.067 \\
(1.53)\end{array}$ & $\begin{array}{c}0.0283^{* *} \\
(2.18)\end{array}$ & $\begin{array}{c}0.0282^{* *} \\
(2.14)\end{array}$ & \\
\hline Checking \& Uninsured & 1.152 & 0.0332 & 0.0416 & \\
\hline$\rightarrow$ Later Covered by TAG/DFA & $(1.36)$ & $(1.07)$ & $(1.30)$ & \\
\hline Checking & $\begin{array}{l}0.591^{* * *} \\
(-10.43)\end{array}$ & $\begin{array}{c}-0.152^{* * *} \\
(-11.46)\end{array}$ & $\begin{array}{c}-0.145^{* * *} \\
(-12.45)\end{array}$ & \\
\hline Direct Deposit & $\begin{array}{c}0.647^{* * *} \\
(-7.14)\end{array}$ & $\begin{array}{c}-0.120^{* * *} \\
(-7.04)\end{array}$ & $\begin{array}{c}-0.116^{* * *} \\
(-7.62)\end{array}$ & \\
\hline Log(Age) & $\begin{array}{c}0.986 \\
(-1.05)\end{array}$ & $\begin{array}{c}-0.00399 \\
(-0.94)\end{array}$ & $\begin{array}{c}-0.00328 \\
(-0.77)\end{array}$ & \\
\hline Prior Transactions & $\begin{array}{l}1.053^{* * *} \\
(18.95)\end{array}$ & $\begin{array}{c}0.0126^{* * *} \\
(16.67)\end{array}$ & $\begin{array}{c}0.0134^{* * *} \\
(16.87)\end{array}$ & $\dagger+\dagger$ \\
\hline Prior Transactions ${ }^{2}$ & $\begin{array}{l}0.999^{* * *} \\
(-15.30)\end{array}$ & $\begin{array}{c}-0.000169^{* * *} \\
(-15.36)\end{array}$ & $\begin{array}{c}-0.000189^{* * *} \\
(-15.08)\end{array}$ & $\dagger \dagger$ \\
\hline Institutional - Any & $\begin{array}{l}1.076 \\
(0.88)\end{array}$ & $\begin{array}{l}0.0234 \\
(0.98)\end{array}$ & $\begin{array}{l}0.0229 \\
(0.92)\end{array}$ & \\
\hline Trust & $\begin{array}{l}1.014 \\
(0.13)\end{array}$ & $\begin{array}{l}0.0262 \\
(0.86)\end{array}$ & $\begin{array}{l}0.0273 \\
(0.87)\end{array}$ & \\
\hline Branch Controls & Yes & Yes & Yes & \\
\hline$N$ & 9897521 & 34476 & 34476 & \\
\hline Log Likelihood & -132171.2 & -23717.7 & -22606.0 & \\
\hline Model P-Value & $<0.001$ & $<0.001$ & $<0.001$ & \\
\hline No. of Liquidations & 12960 & 12960 & 12960 & \\
\hline
\end{tabular}

Estimates from Cox proportional hazard, linear probability, and probit models for the probability of account liquidation during the pre-crisis period. Liquidation is defined as withdrawing more than $50 \%$ of the account balance and remaining below that level for 61 days or more. Cox estimates are expressed as hazard ratios, LPM estimates are OLS coefficient estimates, and Probit estimates are marginal effects. T-statistics are in parentheses. Estimates significant at $1 \%$ are denoted with ${ }^{* * *}, 5 \%$ with ${ }^{* *}$, and $10 \%$ with ${ }^{*}$. Column (4) indicates whether the hazard rate for the Cox model (in column (1)) is statistically different from the corresponding estimate in the Placebo period. Differences significant at the $1 \%$ level are represented by $\dagger \dagger \uparrow, 5 \%$ by $\dagger \dagger$, and $10 \%$ by $\dagger$. 
Table 5: Who Withdraws? Post-Crisis Period; Transaction Deposits

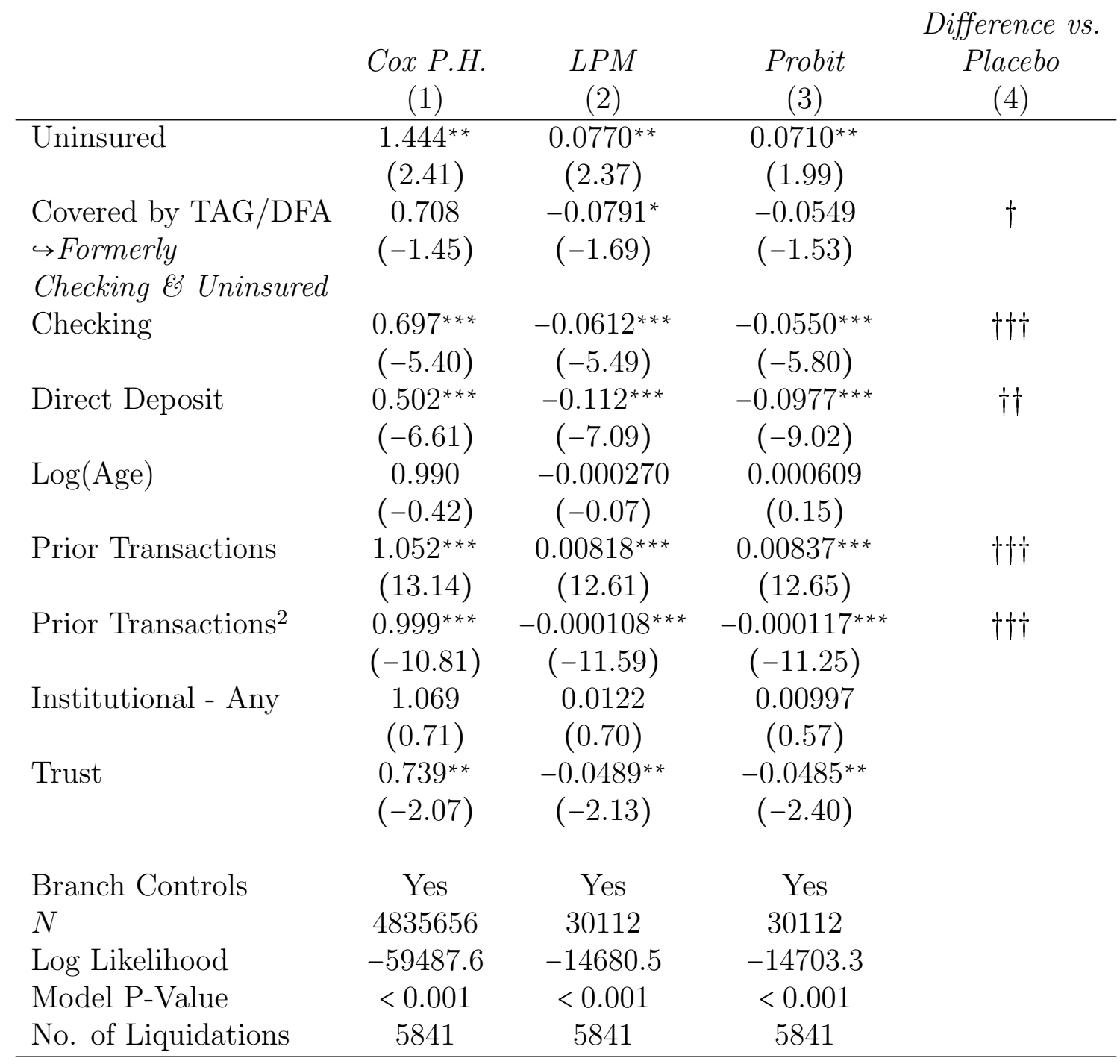

Estimates from Cox proportional hazard, linear probability, and probit models for the probability of account liquidation during the post-crisis period. Liquidation is defined as withdrawing more than $50 \%$ of the account balance and remaining below that level for 61 days or more. Cox estimates are expressed as hazard ratios, LPM estimates are OLS coefficient estimates, and Probit estimates are marginal effects. T-statistics are in parentheses. Estimates significant at $1 \%$ are denoted with ${ }^{* * *}, 5 \%$ with ${ }^{* *}$, and $10 \%$ with ${ }^{*}$. Column (4) indicates whether the hazard rate for the Cox model (in column (1)) is statistically different from the corresponding estimate in the Placebo period. Differences significant at the $1 \%$ level are represented by $\dagger \uparrow \uparrow, 5 \%$ by $\dagger \dagger$, and $10 \%$ by $\dagger$. 
Table 6: Who Withdraws? Formal Enforcement Action; Transaction Deposits

\begin{tabular}{lcccc} 
& Cox P.H. & LPM & Probit & $\begin{array}{c}\text { Difference vs. } \\
\text { Placebo } \\
\end{array}$ \\
& $(1)$ & $(2)$ & $(3)$ & $(4)$ \\
\hline Uninsured & $1.919^{* * *}$ & $0.230^{* * *}$ & $0.224^{* * *}$ & $\dagger \dagger \dagger$ \\
& $(10.00)$ & $(10.76)$ & $(9.10)$ & \\
Covered by DFA & 0.844 & $-0.0792^{*}$ & -0.0577 & \\
$\hookrightarrow$ Formerly & $(-1.11)$ & $(-1.67)$ & $(-1.44)$ & \\
Covered by TAG/DFA & & & & \\
Checking & $0.805^{* * *}$ & $-0.0625^{* * *}$ & $-0.0597^{* * *}$ & $\dagger \dagger \dagger$ \\
& $(-4.38)$ & $(-5.15)$ & $(-5.37)$ & \\
Direct Deposit & $0.735^{* * *}$ & $-0.0548^{* * *}$ & $-0.0579^{* * *}$ & \\
& $(-3.87)$ & $(-3.14)$ & $(-3.61)$ & \\
Log(Age) & $0.936^{* * *}$ & $-0.0147^{* * *}$ & $-0.0139^{* *}$ & $\dagger \dagger$ \\
& $(-3.11)$ & $(-2.63)$ & $(-2.53)$ & \\
Prior Transactions & $1.013^{* * *}$ & $0.00448^{* * *}$ & $0.00467^{* * *}$ & $\dagger \dagger \dagger$ \\
& $(3.95)$ & $(5.77)$ & $(5.85)$ & \\
Prior Transactions ${ }^{2}$ & $1.000^{* * *}$ & $-0.0000698^{* * *}$ & $-0.0000752^{* * *}$ & $\dagger \dagger \dagger$ \\
& $(-4.77)$ & $(-6.48)$ & $(-6.47)$ & \\
Institutional - Any & 0.997 & -0.00184 & -0.00250 & \\
& $(-0.04)$ & $(-0.11)$ & $(-0.16)$ & \\
Trust & $1.169^{* *}$ & $0.0577^{* * *}$ & $0.0533^{* *}$ & \\
& $(2.11)$ & $(2.68)$ & $(2.37)$ & \\
Branch Controls & & & & \\
$N$ & Yes & Yes & Yes & \\
Log Likelihood & 7032455 & 27145 & 27145 & \\
Model P-Value & -74902.1 & -16439.4 & -15786.8 & \\
No. of Liquidations & $<0.001$ & $<0.001$ & $<0.001$ & \\
\hline & 7547 & 7547 & 7547 & \\
\hline
\end{tabular}

Estimates from Cox proportional hazard, linear probability, and probit models for the probability of account liquidation in response to the formal enforcement action. Liquidation is defined as withdrawing more than $50 \%$ of the account balance and remaining below that level for 61 days or more. Cox estimates are expressed as hazard ratios, LPM estimates are OLS coefficient estimates, and Probit estimates are marginal effects. T-statistics are in parentheses. Estimates significant at $1 \%$ are denoted with ${ }^{* * *}, 5 \%$ with ${ }^{* *}$, and $10 \%$ with ${ }^{*}$. Column (4) indicates whether the hazard rate for the Cox model (in column (1)) is statistically different from the corresponding estimate in the Placebo period. Differences significant at the $1 \%$ level are represented by $\dagger \dagger \dagger, 5 \%$ by $\dagger \dagger$, and $10 \%$ by $\dagger$. 
Table 7: Who Withdraws? Placebo Period; Term Deposits

\begin{tabular}{lccc} 
& Cox P.H. & LPM & Probit \\
& $(1)$ & $(2)$ & $(3)$ \\
\hline Uninsured & 1.023 & 0.00349 & 0.00524 \\
& $(0.35)$ & $(0.23)$ & $(0.33)$ \\
Log(Age) & 0.975 & $-0.00802^{*}$ & $-0.00879^{*}$ \\
& $(-1.35)$ & $(-1.86)$ & $(-1.90)$ \\
Log(Days to Maturity) & $0.641^{* * *}$ & $-0.130^{* * *}$ & $-0.136^{* * *}$ \\
& $(-25.98)$ & $(-24.22)$ & $(-23.05)$ \\
Placed & $2.935^{* * *}$ & $0.203^{* * *}$ & $0.221^{* * *}$ \\
& $(14.10)$ & $(9.27)$ & $(8.48)$ \\
Institutional - Listed/Faxed & - & - & - \\
$\rightarrow$ Omitted - too few obs. & - & - & - \\
Institutional - Other & $1.681^{* * *}$ & 0.0634 & 0.0666 \\
& $(2.65)$ & $(1.30)$ & $(1.16)$ \\
Trust & $0.735^{* *}$ & $-0.0708^{* * *}$ & $-0.0801^{* * *}$ \\
& $(-2.49)$ & $(-2.78)$ & $(-3.15)$ \\
& & & \\
Branch Controls & Yes & Yes & Yes \\
$N$ & 1180628 & 6567 & 6566 \\
Log Likelihood & -15734.6 & -4012.7 & -3822.4 \\
Model P-Value & $<0.001$ & $<0.001$ & $<0.001$ \\
No. of Liquidations & 1867 & 1867 & 1867 \\
\hline
\end{tabular}

Estimates from Cox proportional hazard, linear probability, and probit models for the probability of account liquidation during the placebo period, well before the financial crisis. Liquidation is defined as withdrawing more than $50 \%$ of the account balance and remaining below that level for 61 days or more. Cox estimates are expressed as hazard ratios, LPM estimates are OLS coefficient estimates, and Probit estimates are marginal effects. T-statistics are in parentheses. Estimates significant at $1 \%$ are denoted with ${ }^{* * *}, 5 \%$ with ${ }^{* *}$, and $10 \%$ with *. 
Table 8: Who Withdraws? Pre-Crisis Period; Term Deposits

\begin{tabular}{|c|c|c|c|c|}
\hline & $\begin{array}{c}\text { Cox P.H. } \\
\text { (1) }\end{array}$ & $\begin{array}{c}L P M \\
(2)\end{array}$ & $\begin{array}{c}\text { Probit } \\
\text { (3) }\end{array}$ & $\begin{array}{c}\text { Difference vs. } \\
\text { Placebo } \\
\text { (4) }\end{array}$ \\
\hline Uninsured & $\begin{array}{c}1.173^{* * *} \\
(4.73)\end{array}$ & $\begin{array}{c}0.0487^{* * *} \\
(4.21)\end{array}$ & $\begin{array}{c}0.0495^{* * *} \\
(4.31)\end{array}$ & $\dagger$ \\
\hline Log(Age) & $\begin{array}{c}0.938^{* * *} \\
(-6.12)\end{array}$ & $\begin{array}{c}-0.0385^{* * *} \\
(-10.29)\end{array}$ & $\begin{array}{c}-0.0398^{* * *} \\
(-10.27)\end{array}$ & $\dagger$ \\
\hline Log(Days to Maturity) & $\begin{array}{l}0.783^{* * *} \\
(-27.62)\end{array}$ & $\begin{array}{c}-0.0599^{* * *} \\
(-18.35)\end{array}$ & $\begin{array}{c}-0.0631^{* * *} \\
(-18.01)\end{array}$ & $t+\dagger$ \\
\hline Placed & $\begin{array}{c}3.042^{* * *} \\
(19.74)\end{array}$ & $\begin{array}{c}0.179^{* * *} \\
(7.90)\end{array}$ & $\begin{array}{c}0.200^{* * *} \\
(11.33)\end{array}$ & \\
\hline Institutional - Listed/Faxed & $\begin{array}{c}0.308 \\
(-1.18)\end{array}$ & $\begin{array}{l}-0.400^{*} \\
(-1.94)\end{array}$ & $\begin{array}{c}-0.413^{* *} \\
(-2.00)\end{array}$ & \\
\hline Institutional - Other & $\begin{array}{c}1.730^{* * *} \\
(3.77)\end{array}$ & $\begin{array}{l}0.0829 \\
(1.60)\end{array}$ & $\begin{array}{c}0.0873^{*} \\
(1.82)\end{array}$ & \\
\hline Trust & $\begin{array}{l}1.011 \\
(0.17)\end{array}$ & $\begin{array}{c}0.000833 \\
(0.04)\end{array}$ & $\begin{array}{c}0.00320 \\
(0.14)\end{array}$ & $\dagger \dagger$ \\
\hline Branch Controls & Yes & Yes & Yes & \\
\hline$N$ & 2487654 & 10438 & 10436 & \\
\hline Log Likelihood & -50099.8 & -6700.0 & -6374.4 & \\
\hline Model P-Value & $<0.001$ & $<0.001$ & $<0.001$ & \\
\hline No. of Liquidations & 5749 & 5749 & 5749 & \\
\hline
\end{tabular}

Estimates from Cox proportional hazard, linear probability, and probit models for the probability of account liquidation during the pre-crisis period. Liquidation is defined as withdrawing more than $50 \%$ of the account balance and remaining below that level for 61 days or more. Cox estimates are expressed as hazard ratios, LPM estimates are OLS coefficient estimates, and Probit estimates are marginal effects. T-statistics are in parentheses. Estimates significant at $1 \%$ are denoted with ${ }^{* *}, 5 \%$ with ${ }^{* *}$, and $10 \%$ with ${ }^{*}$. Column (4) indicates whether the hazard rate for the Cox model (in column (1)) is statistically different from the corresponding estimate in the Placebo period. Differences significant at the $1 \%$ level are represented by $\dagger \uparrow \uparrow, 5 \%$ by $\dagger \dagger$, and $10 \%$ by $\dagger$. 
Table 9: Who Withdraws? Post-Crisis Period; Term Deposits

\begin{tabular}{lcccc} 
& Cox P.H. & LPM & Probit & $\begin{array}{c}\text { Difference vs. } \\
\text { Placebo } \\
\end{array}$ \\
& $1.641^{* *}$ & $0.0691^{*}$ & $0.0882^{*}$ & $\dagger$ \\
\hline Uninsured & $(2.51)$ & $(1.86)$ & $(1.68)$ & \\
& $0.950^{* *}$ & -0.00148 & -0.00145 & \\
Log(Age) & $(-2.29)$ & $(-0.38)$ & $(-0.28)$ & \\
& $0.470^{* * *}$ & $-0.194^{* * *}$ & $-0.209^{* * *}$ & $\dagger \dagger \dagger$ \\
Log(Days to Maturity) & $(-55.79)$ & $(-52.97)$ & $(-42.52)$ & \\
& $5.592^{* * *}$ & $0.284^{* * *}$ & $0.345^{* * *}$ & $\dagger \dagger \dagger$ \\
Placed & $(25.20)$ & $(21.63)$ & $(17.66)$ & \\
& 0.886 & -0.0328 & -0.128 & \\
Institutional - Listed/Faxed & $(-0.17)$ & $(-0.40)$ & $(-1.22)$ & \\
& 0.741 & -0.00493 & -0.0443 & $\dagger \dagger \dagger$ \\
Institutional - Other & $(-1.36)$ & $(-0.15)$ & $(-1.02)$ & \\
& 1.047 & -0.00842 & -0.0146 & $\dagger$ \\
Trust & $(0.29)$ & $(-0.36)$ & $(-0.47)$ & \\
& & & & \\
Branch Controls & Yes & Yes & Yes & \\
$N$ & 1263007 & 8328 & 8328 & \\
Log Likelihood & -18393.4 & -3803.9 & -3738.6 & \\
Model P-Value & $<0.001$ & $<0.001$ & $<0.001$ & \\
No. of Liquidations & 2251 & 2251 & 2251 & \\
\hline
\end{tabular}

Estimates from Cox proportional hazard, linear probability, and probit models for the probability of account liquidation during the post-crisis period. Liquidation is defined as withdrawing more than $50 \%$ of the account balance and remaining below that level for 61 days or more. Cox estimates are expressed as hazard ratios, LPM estimates are OLS coefficient estimates, and Probit estimates are marginal effects. T-statistics are in parentheses. Estimates significant at $1 \%$ are denoted with ${ }^{* *}, 5 \%$ with ${ }^{* *}$, and $10 \%$ with ${ }^{*}$. Column (4) indicates whether the hazard rate for the Cox model (in column (1)) is statistically different from the corresponding estimate in the Placebo period. Differences significant at the $1 \%$ level are represented by $\dagger \dagger \uparrow, 5 \%$ by $\dagger \dagger$, and $10 \%$ by $\dagger$. 
Table 10: Who Withdraws? Formal Enforcement Action; Term Deposits

\begin{tabular}{|c|c|c|c|c|}
\hline & $\begin{array}{c}\text { Cox P.H. } \\
\text { (1) }\end{array}$ & $\begin{array}{c}L P M \\
(2)\end{array}$ & $\begin{array}{c}\text { Probit } \\
\text { (3) }\end{array}$ & $\begin{array}{c}\text { Difference vs. } \\
\text { Placebo } \\
(4)\end{array}$ \\
\hline Uninsured & $\begin{array}{c}1.666^{* * *} \\
(2.61)\end{array}$ & $\begin{array}{c}0.0983^{* *} \\
(2.02)\end{array}$ & $\begin{array}{l}0.109^{*} \\
(1.89)\end{array}$ & $t \dagger$ \\
\hline Log(Age) & $\begin{array}{l}1.034 \\
(1.19)\end{array}$ & $\begin{array}{l}-0.0120 \\
(-1.61)\end{array}$ & $\begin{array}{c}-0.0176^{*} \\
(-1.66)\end{array}$ & $\dagger$ \\
\hline Log(Days to Maturity) & $\begin{array}{l}0.592^{* * *} \\
(-27.36)\end{array}$ & $\begin{array}{c}-0.0601^{* * *} \\
(-10.82)\end{array}$ & $\begin{array}{c}-0.0799^{* * * *} \\
(-10.53)\end{array}$ & t†† \\
\hline Placed & $\begin{array}{c}14.29^{* * *} \\
(29.46)\end{array}$ & $\begin{array}{c}0.597^{* * *} \\
(26.50)\end{array}$ & $\begin{array}{c}0.616^{* * *} \\
(36.33)\end{array}$ & t†† \\
\hline Institutional - Listed/Faxed & $\begin{array}{c}1.858^{* * *} \\
(3.38)\end{array}$ & $\begin{array}{c}0.0927^{* *} \\
(1.99)\end{array}$ & $\begin{array}{c}0.0968^{*} \\
(1.71)\end{array}$ & \\
\hline Institutional - Other & $\begin{array}{l}1.396^{* *} \\
(2.18)\end{array}$ & $\begin{array}{l}-0.0313 \\
(-0.95)\end{array}$ & $\begin{array}{l}-0.0438 \\
(-0.98)\end{array}$ & \\
\hline Trust & $\begin{array}{c}1.401^{* *} \\
(2.23)\end{array}$ & $\begin{array}{c}0.00166 \\
(0.05)\end{array}$ & $\begin{array}{c}0.00398 \\
(0.09)\end{array}$ & t†† \\
\hline Branch Controls & Yes & Yes & Yes & \\
\hline$N$ & 855693 & 3511 & 3508 & \\
\hline Log Likelihood & -11783.6 & -1803.7 & -1729.4 & \\
\hline Model P-Value & $<0.001$ & $<0.001$ & $<0.001$ & \\
\hline No. of Liquidations & 1629 & 1629 & 1629 & \\
\hline
\end{tabular}

Estimates from Cox proportional hazard, linear probability, and probit models for the probability of account liquidation in response to the formal enforcement action. Liquidation is defined as withdrawing more than $50 \%$ of the account balance and remaining below that level for 61 days or more. Cox estimates are expressed as hazard ratios, LPM estimates are OLS coefficient estimates, and Probit estimates are marginal effects. T-statistics are in parentheses. Estimates significant at $1 \%$ are denoted with ${ }^{* * *}, 5 \%$ with ${ }^{* *}$, and $10 \%$ with ${ }^{*}$. Column (4) indicates whether the hazard rate for the Cox model (in column (1)) is statistically different from the corresponding estimate in the Placebo period. Differences significant at the $1 \%$ level are represented by $\dagger \dagger \dagger, 5 \%$ by $\dagger \dagger$, and $10 \%$ by $\dagger$. 
Table 11: Uninsured Transaction Account Migration

Deposit Insurance Limit $=\$ 100,000$

\begin{tabular}{|c|c|c|c|c|c|c|}
\hline Bin Range & $<\$ 1$ & $\$ 1-2,000$ & $\begin{array}{l}\$ 2,000- \\
48,000\end{array}$ & $\begin{array}{c}\$ 48,000- \\
98,000\end{array}$ & $\begin{array}{l}\$ 98,000- \\
102,000\end{array}$ & $>\$ 102,000$ \\
\hline Placebo & $5.8 \%$ & $8.2 \%$ & $11.4 \%$ & $10.3 \%$ & $11.7 \%$ & $52.6 \%$ \\
\hline Pre-Crisis & $9.0 \%$ & $8.1 \%$ & $9.9 \%$ & $15.5 \%$ & $16.2 \%$ & $41.3 \%$ \\
\hline \multicolumn{7}{|c|}{ Deposit Insurance Limit $=\$ 250,000$} \\
\hline Bin Range & $<\$ 1$ & $\$ 1-2,000$ & $\begin{array}{l}\$ 2,000- \\
123,000\end{array}$ & $\begin{array}{c}\$ 123,000- \\
248,000\end{array}$ & $\begin{array}{c}\$ 248,000- \\
252,000\end{array}$ & $>\$ 252,000$ \\
\hline Post-Crisis & $2.1 \%$ & $6.0 \%$ & $14.5 \%$ & $12.0 \%$ & $1.7 \%$ & $63.7 \%$ \\
\hline Formal & $21.7 \%$ & $6.4 \%$ & $21.9 \%$ & $14.4 \%$ & $7.8 \%$ & $27.6 \%$ \\
\hline
\end{tabular}

For all transaction accounts which had a balance of $\$ 2,000$ shy of the current deposit insurance limit or higher at the beginning of each period, this table shows their distribution into various account dollar-size bins at the end of the period. 
Table 12: New Depositor Characteristics

\begin{tabular}{lcccc} 
& Placebo & Pre-Crisis & Post-Crisis & Formal \\
& $(1)$ & $(2)$ & $(3)$ & $(4)$ \\
\hline Uninsured & $-0.0798^{* * *}$ & $-0.0538^{* * *}$ & $-0.0785^{* * *}$ & $-0.0509^{* * *}$ \\
& $(-16.00)$ & $(-16.58)$ & $(-9.64)$ & $(-8.85)$ \\
Covered by TAG/DFA & $0.0707^{* * *}$ & $-0.0398^{* * *}$ & 0.00123 & -0.0150 \\
$\rightarrow$ Or & $(4.33)$ & $(-3.67)$ & $(0.09)$ & $(-1.10)$ \\
Checking \& Uninsured & & & & \\
Checking & $-0.0315^{* * *}$ & $-0.0137^{* * *}$ & $-0.0191^{* * *}$ & -0.00348 \\
& $(-6.83)$ & $(-3.69)$ & $(-6.78)$ & $(-1.26)$ \\
Term Deposit & $0.106^{* * *}$ & $0.0475^{* * *}$ & $0.00447^{* *}$ & $0.0718^{* * *}$ \\
& $(36.24)$ & $(23.55)$ & $(2.49)$ & $(27.26)$ \\
Placed & $-0.148^{* * *}$ & 0.0000419 & $0.0614^{* * *}$ & $-0.0746^{* * *}$ \\
& $(-14.38)$ & $(0.01)$ & $(17.95)$ & $(-16.39)$ \\
Institutional - Listed/Faxed & -0.153 & $0.631^{* * *}$ & $0.517^{* * *}$ & $0.869^{* * *}$ \\
& $(-1.44)$ & $(15.53)$ & $(27.00)$ & $(215.92)$ \\
Institutional - Other & $0.0281^{* * *}$ & $0.309^{* * *}$ & $0.0818^{* * *}$ & $0.0336^{* * *}$ \\
& $(2.63)$ & $(50.53)$ & $(17.93)$ & $(8.52)$ \\
Trust & 0.0106 & -0.00139 & $0.0249^{* * *}$ & $0.0389^{* * *}$ \\
& $(1.19)$ & $(-0.22)$ & $(4.68)$ & $(7.43)$ \\
Branch Controls & & & & \\
$N$ & Yes & Yes & Yes & Yes \\
Log Likelihood & 45115 & 48204 & 39740 & 33313 \\
Model P-Value & 980.0 & 13890.7 & 23623.9 & 20255.6 \\
\hline
\end{tabular}

Estimates of account-level regressions, with one observation per account that is extant at the start of that period or that will arrive during that period, of a dummy variable which equals one for newly arrived depositors' accounts and zero otherwise, on account characteristics. The results show what deposit(or) attributes were associated with new deposit(or)s. All models are estimated with OLS. T-statistics are in parentheses. Estimates significant at $1 \%$ are denoted with ${ }^{* *}, 5 \%$ with ${ }^{* *}$, and $10 \%$ with *. 
Table 13: What Explains the Share of Depositors that Are New?

(1)

\begin{tabular}{|c|c|c|c|}
\hline \multicolumn{4}{|l|}{ Time Period Dummies: } \\
\hline Pre-Placebo & $\begin{array}{c}0.000509^{* * *} \\
(2.68)\end{array}$ & $\begin{array}{c}0.000139 \\
(1.50)\end{array}$ & $\begin{array}{c}0.000142 \\
(1.58)\end{array}$ \\
\hline Placebo to Pre-Crisis & $\begin{array}{c}0.000179^{*} \\
(1.77)\end{array}$ & $\begin{array}{c}0.000141^{* *} \\
(2.03)\end{array}$ & $\begin{array}{c}0.000150^{* *} \\
(2.19)\end{array}$ \\
\hline Pre-Crisis & $\begin{array}{c}-0.000159^{\star * \star} \\
(-2.94)\end{array}$ & $\begin{array}{c}0.0000226 \\
(0.16)\end{array}$ & $\begin{array}{c}0.0000323 \\
\quad(0.24)\end{array}$ \\
\hline Crisis & $\begin{array}{c}0.000000299 \\
(0.00)\end{array}$ & $\begin{array}{c}0.000200 \\
(0.86)\end{array}$ & $\begin{array}{c}0.000191 \\
(0.86)\end{array}$ \\
\hline Post-Crisis & $\begin{array}{c}-0.0000613 \\
(-0.96)\end{array}$ & $\begin{array}{c}0.000214 \\
(0.80)\end{array}$ & $\begin{array}{c}0.000215 \\
(0.84)\end{array}$ \\
\hline Post-Crisis to Formal & $\begin{array}{c}-0.000134^{* *} \\
(-2.37)\end{array}$ & $\begin{array}{c}0.000114 \\
(0.48)\end{array}$ & $\begin{array}{c}0.000106 \\
(0.47)\end{array}$ \\
\hline Formal & $\begin{array}{c}0.000535^{* * *} \\
(2.58)\end{array}$ & $\begin{array}{c}0.000570^{* *} \\
(2.16)\end{array}$ & $\begin{array}{c}0.000578^{* *} \\
(2.27)\end{array}$ \\
\hline \multicolumn{4}{|l|}{ Macro Controls: } \\
\hline $\log (\mathrm{VIX})$ & & $\begin{array}{c}0.000225^{* * *} \\
(2.71)\end{array}$ & $\begin{array}{c}0.000224^{* * *} \\
(2.74)\end{array}$ \\
\hline GDP Growth & & $\begin{array}{c}0.0000246^{* * *} \\
(2.60)\end{array}$ & $\begin{array}{c}0.0000266^{* * *} \\
(2.67)\end{array}$ \\
\hline Housing Starts & & $\begin{array}{c}0.000000325 \\
\quad(1.46)\end{array}$ & $\begin{array}{c}0.000000314 \\
(1.47)\end{array}$ \\
\hline Daily S\&P500 Return & & $\begin{array}{c}0.00240^{*} \\
(1.78)\end{array}$ & $\begin{array}{c}0.00221^{*} \\
(1.68)\end{array}$ \\
\hline Daily Deposit Growth & & & $\begin{array}{c}0.0146 \\
(1.64)\end{array}$ \\
\hline $\operatorname{AR}(1)$ & & $\begin{array}{c}0.448^{* * *} \\
(13.63)\end{array}$ & $\begin{array}{c}0.436^{* * *} \\
(12.88)\end{array}$ \\
\hline Constant & $\begin{array}{c}0.000295^{* * *} \\
(5.94)\end{array}$ & $\begin{array}{c}-0.000993^{\star \star} \\
(-2.21)\end{array}$ & $\begin{array}{c}-0.000980^{* *} \\
(-2.25)\end{array}$ \\
\hline$N$ & 2079 & 2078 & 2078 \\
\hline Model P-Value & $<0.001$ & $<0.001$ & $<0.001$ \\
\hline
\end{tabular}

Estimates from daily-frequency regressions of the share of depositors at the bank who are new (as of that day) on various controls. All models are OLS, with Newey-West standard errors of lag length 9 . Estimates significant at $1 \%$ are denoted with ${ }^{* * *}, 5 \%$ with ${ }^{* *}$, and $10 \%$ with *. 
Table 14: Impact of Regulatory Action on Funding Shares For US Banks

\begin{tabular}{lccccc} 
& Brokered & Listed & Sm. Term & Med. Term & Lg. Term \\
& $(1)$ & $(2)$ & $(3)$ & $(4)$ & $(5)$ \\
\hline Under Reg. Action & $-0.0124^{* * *}$ & $0.00826^{* * *}$ & $0.00364^{* * *}$ & $0.00466^{* * *}$ & $-0.00830^{* * *}$ \\
& $(-22.72)$ & $(11.40)$ & $(5.21)$ & $(6.25)$ & $(-12.10)$ \\
NPL $_{t} / A_{t}$ & $0.000102^{* *}$ & 0.0000224 & $0.00117^{* * *}$ & -0.0000903 & $-0.00108^{* * *}$ \\
& $(2.38)$ & $(0.42)$ & $(22.32)$ & $(-1.62)$ & $(-20.97)$ \\
$\% \Delta A_{t}$ & $0.000238^{* * *}$ & $0.000127^{* * *}$ & $-0.000282^{* * *}$ & $0.000215^{* * *}$ & $0.0000668^{* * *}$ \\
& $(54.53)$ & $(18.82)$ & $(-41.97)$ & $(29.95)$ & $(10.13)$ \\
$\ln \left(A_{t}\right)$ & $0.0283^{* * *}$ & $0.00354^{* * *}$ & $0.0127^{* * *}$ & $-0.00837^{* * *}$ & $-0.00432^{* * *}$ \\
& $(137.87)$ & $(8.31)$ & $(31.87)$ & $(-19.66)$ & $(-11.05)$ \\
Deposits $t / A_{t}$ & $0.0429^{* * *}$ & $0.0162^{* * *}$ & $0.0179^{* * *}$ & $0.0181^{* * *}$ & $-0.0360^{* * *}$ \\
& $(35.62)$ & $(7.44)$ & $(8.33)$ & $(7.92)$ & $(-17.11)$ \\
Term Dep $/ A_{t}$ & $0.144^{* * *}$ & $0.162^{* * *}$ & $0.291^{* * *}$ & $0.393^{* * *}$ & $0.316^{* * *}$ \\
Constant & $(173.14)$ & $(112.02)$ & $(211.50)$ & $(267.68)$ & $(234.54)$ \\
& $-0.419^{* * *}$ & $-0.116^{* * *}$ & $-0.0358^{* * *}$ & $0.0415^{* * *}$ & -0.00575 \\
Bank \& Quarter FE & $(-176.09)$ & $(-22.44)$ & $(-7.40)$ & $(8.04)$ & $(-1.21)$ \\
$N$ & & & & & \\
$R^{2}$ & Yes & Yes & Yes & Yes & Yes \\
Model P-Value & 554180 & 162123 & 193306 & 193306 & 193306 \\
\hline
\end{tabular}

Estimates from regressing funding shares on a regulatory action dummy and bank-level controls for all US banks from 2000 to 2016. The regulatory action dummy is based on public and confidential supervisory data; other variables are from the regulatory filings of all US banks. Observational units are bank-quarters, with brokered deposit data available from 2000 to 2016, listing service deposits from 2011 to 2016, and all other term deposit data from 2010 to 2016. Small term deposits are those with balances of $\$ 100,000$ or less; medium term deposits are between $\$ 100,001$ and $\$ 250,000$; and large term deposits are those over $\$ 250,000$. T-statistics in parentheses. Estimates significant at $1 \%$ are denoted with ${ }^{* *}, 5 \%$ with ${ }^{* *}$, and $10 \%$ with *. 
Table 15: Impact of Regulatory Action on Funding Shares For US Banks, Quarterly Dummies

\begin{tabular}{|c|c|c|c|c|c|}
\hline & $\begin{array}{l}\text { Brokered } \\
\text { (1) }\end{array}$ & $\begin{array}{l}\text { Listed } \\
(2)\end{array}$ & $\begin{array}{c}\text { Sm. Term } \\
\text { (3) }\end{array}$ & $\begin{array}{c}\text { Med. Term } \\
\text { (4) }\end{array}$ & $\begin{array}{l}\text { Lg. Term } \\
(5)\end{array}$ \\
\hline$(t-4)$ & $\begin{array}{c}0.0117^{* * *} \\
(11.71)\end{array}$ & $\begin{array}{c}-0.00958^{* * *} \\
(-5.00)\end{array}$ & $\begin{array}{c}0.00443^{* *} \\
(2.49)\end{array}$ & $\begin{array}{c}-0.00857^{* * *} \\
(-4.51)\end{array}$ & $\begin{array}{c}0.00414^{* *} \\
(2.37)\end{array}$ \\
\hline$(t-3)$ & $\begin{array}{c}0.0107^{* * *} \\
(11.12)\end{array}$ & $\begin{array}{c}-0.00951^{* * *} \\
(-5.63)\end{array}$ & $\begin{array}{l}0.00725^{* * *} \\
\quad(4.68)\end{array}$ & $\begin{array}{c}-0.00863^{* * *} \\
(-5.22)\end{array}$ & $\begin{array}{c}0.00138 \\
(0.91)\end{array}$ \\
\hline$(t-2)$ & $\begin{array}{c}0.00951^{* * *} \\
(10.20)\end{array}$ & $\begin{array}{c}-0.00633^{* * *} \\
(-4.01)\end{array}$ & $\begin{array}{c}0.00759^{* * *} \\
(5.29)\end{array}$ & $\begin{array}{c}-0.00838^{* * *} \\
(-5.46)\end{array}$ & $\begin{array}{c}0.000785 \\
(0.56)\end{array}$ \\
\hline$(t-1)$ & $\begin{array}{c}0.00704^{* * *} \\
(8.03)\end{array}$ & $\begin{array}{c}-0.00535^{* * *} \\
(-3.78)\end{array}$ & $\begin{array}{c}0.00653^{* * *} \\
\quad(5.03)\end{array}$ & $\begin{array}{c}-0.00663^{* * *} \\
(-4.77)\end{array}$ & $\begin{array}{c}0.0000987 \\
(0.08)\end{array}$ \\
\hline$(t)$ & $\begin{array}{c}0.00729^{* * *} \\
(8.33)\end{array}$ & $\begin{array}{c}-0.00260^{*} \\
(-1.91)\end{array}$ & $\begin{array}{c}0.00639^{* * *} \\
(5.14)\end{array}$ & $\begin{array}{c}-0.00559^{* * *} \\
(-4.21)\end{array}$ & $\begin{array}{c}-0.000797 \\
(-0.65)\end{array}$ \\
\hline$(t+1)$ & $\begin{array}{c}0.00512^{* * *} \\
(4.03)\end{array}$ & $\begin{array}{l}0.0000124 \\
\quad(0.01)\end{array}$ & $\begin{array}{c}0.0122^{* * *} \\
(7.90)\end{array}$ & $\begin{array}{c}-0.00743^{* * *} \\
(-4.51)\end{array}$ & $\begin{array}{c}-0.00476^{* * *} \\
(-3.14)\end{array}$ \\
\hline$(t+2)$ & $\begin{array}{c}-0.00667^{* * *} \\
(-4.50)\end{array}$ & $\begin{array}{c}0.00477^{* * *} \\
(2.72)\end{array}$ & $\begin{array}{c}0.0140^{* * *} \\
(9.10)\end{array}$ & $\begin{array}{c}-0.00457^{* * *} \\
(-2.77)\end{array}$ & $\begin{array}{c}-0.00945^{* * *} \\
(-6.25)\end{array}$ \\
\hline$(t+3)$ & $\begin{array}{c}-0.0148^{* * *} \\
(-9.13)\end{array}$ & $\begin{array}{c}0.00594^{* * *} \\
(3.54)\end{array}$ & $\begin{array}{c}0.0114^{* * *} \\
(7.63)\end{array}$ & $\begin{array}{c}-0.000210 \\
(-0.13)\end{array}$ & $\begin{array}{c}-0.0112^{* * *} \\
(-7.62)\end{array}$ \\
\hline$(t+4)$ & $\begin{array}{c}-0.0213^{* * *} \\
(-12.53)\end{array}$ & $\begin{array}{c}0.00669^{* * *} \\
(4.10)\end{array}$ & $\begin{array}{c}0.00759^{* * *} \\
(5.06)\end{array}$ & $\begin{array}{c}0.00284^{*} \\
(1.77)\end{array}$ & $\begin{array}{c}-0.0104^{* * *} \\
(-7.08)\end{array}$ \\
\hline$(t+i), i \geq 5$ & $\begin{array}{c}-0.0385^{* * *} \\
(-41.34)\end{array}$ & $\begin{array}{c}0.0121^{* * *} \\
(12.85)\end{array}$ & $\begin{array}{c}-0.00000122 \\
(-0.00)\end{array}$ & $\begin{array}{c}0.0114^{* * *} \\
(11.19)\end{array}$ & $\begin{array}{c}-0.0114^{* * *} \\
(-12.18)\end{array}$ \\
\hline $\mathrm{NPL}_{t} / A_{t}$ & $\begin{array}{c}0.000192^{* * *} \\
(4.43)\end{array}$ & $\begin{array}{c}0.0000499 \\
(0.94)\end{array}$ & $\begin{array}{c}0.00114^{* * *} \\
(21.74)\end{array}$ & $\begin{array}{c}-0.0000804 \\
(-1.43)\end{array}$ & $\begin{array}{c}-0.00106^{* * *} \\
(-20.58)\end{array}$ \\
\hline$\% \Delta A_{t}$ & $\begin{array}{c}0.000233^{* * *} \\
(53.55)\end{array}$ & $\begin{array}{c}0.000126^{* * *} \\
(18.66)\end{array}$ & $\begin{array}{c}-0.000280^{* * *} \\
(-41.63)\end{array}$ & $\begin{array}{c}0.000213^{* * *} \\
(29.65)\end{array}$ & $\begin{array}{c}0.0000668^{* * *} \\
(10.12)\end{array}$ \\
\hline $\ln \left(A_{t}\right)$ & $\begin{array}{c}0.0279^{* * *} \\
(135.80)\end{array}$ & $\begin{array}{c}0.00383^{* * *} \\
(8.98)\end{array}$ & $\begin{array}{c}0.0122^{* * *} \\
(30.38)\end{array}$ & $\begin{array}{c}-0.00761^{* * *} \\
(-17.78)\end{array}$ & $\begin{array}{c}-0.00455^{* * *} \\
(-11.58)\end{array}$ \\
\hline $\operatorname{Deposits}_{t} / A_{t}$ & $\begin{array}{c}0.0433^{* * *} \\
(36.05)\end{array}$ & $\begin{array}{c}0.0155^{* * *} \\
(7.13)\end{array}$ & $\begin{array}{c}0.0186^{* * *} \\
(8.69)\end{array}$ & $\begin{array}{c}0.0165^{* * *} \\
(7.21)\end{array}$ & $\begin{array}{c}-0.0352^{* * *} \\
(-16.70)\end{array}$ \\
\hline Term $\operatorname{Dep}_{t} / A_{t}$ & $\begin{array}{l}0.144^{* * *} \\
(173.11)\end{array}$ & $\begin{array}{l}0.162^{* * *} \\
(112.00)\end{array}$ & $\begin{array}{l}0.290^{* * *} \\
(211.38)\end{array}$ & $\begin{array}{l}0.393^{* * *} \\
(267.89)\end{array}$ & $\begin{array}{l}0.316^{* * *} \\
(234.61)\end{array}$ \\
\hline Constant & $\begin{array}{l}-0.414^{* * *} \\
(-174.03)\end{array}$ & $\begin{array}{c}-0.118^{* * *} \\
(-22.96)\end{array}$ & $\begin{array}{c}-0.0301^{* * *} \\
(-6.22)\end{array}$ & $\begin{array}{c}0.0340^{* * *} \\
(6.56)\end{array}$ & $\begin{array}{c}-0.00384 \\
(-0.81)\end{array}$ \\
\hline Bank \& Quarter FE & Yes & Yes & Yes & Yes & Yes \\
\hline$N$ & 554180 & 162123 & 193306 & 193306 & 193306 \\
\hline$R^{2}$ & 0.139 & 0.085 & 0.688 & 0.339 & 0.241 \\
\hline Model P-Value & $<0.001$ & $<0.001$ & $<0.001$ & $<0.001$ & $<0.001$ \\
\hline
\end{tabular}

Estimates from regressing funding shares on quarterly regulatory action dummies and banklevel controls for all US banks from 2000 to 2016. The regulatory action dummies are based on public and confidential supervisory data; other variables are from the regulatory filings of US banks. Observational units are bank-quarters, with brokered deposit data available from 2000 to 2016, listing service deposits from 2011 to 2016, and all other term deposit data from 2010 to 2016. T-statistics in parentheses. Small term deposits are those with balances of $\$ 100,000$ or less; medium term deposits are between $\$ 100,001$ and $\$ 250,000$; and large term deposits are those over $\$ 250,000$. Time period $t$ is the quarter in which the regulatory action began. Estimates significant at $1 \%$ are denoted with ${ }^{* *}, 5 \%$ with ${ }^{* *}$, and $10 \%$ with *. 
Table 16: Matched Effects of Regulatory Action on Funding Shares for All US Banks, 4 Quarters after Treatment

\begin{tabular}{lccccc} 
& $\begin{array}{c}\text { Brokered } \\
(1)\end{array}$ & $\begin{array}{c}\text { Listed } \\
(2)\end{array}$ & $\begin{array}{c}\text { Sm. Term } \\
(3)\end{array}$ & $\begin{array}{c}\text { Med. Term } \\
(4)\end{array}$ & Lg. Term \\
& $(5)$ \\
\hline Untreated & 0.0407 & 0.0312 & 0.1754 & 0.1421 & 0.0527 \\
Matched Untreated & 0.0365 & 0.0437 & 0.1996 & 0.1677 & 0.0517 \\
Treated & 0.0195 & 0.0998 & 0.2341 & 0.2278 & 0.0430 \\
T-Stat on Differences & -3.46 & 3.90 & 3.88 & 4.73 & -2.63 \\
& & & & & \\
$N$ Untreated & 29611 & 29597 & 29597 & 29597 & 29597 \\
$N$ Treated & 142 & 142 & 142 & 142 & 142 \\
\hline
\end{tabular}

Estimates from propensity-score-matching for a regulatory treatment based on bank covariates to measure the effects on certain deposit products as a share of total deposits for all US Banks. The regulatory action dummy is based on a combination of public and confidential supervisory data; all other variables are from the regulatory filings of all US banks. Observation units are bank-quarters, with brokered deposit data available from 2000 to 2016, listing service deposits from 2011 to 2016, and all other term deposit data from 2010 to 2016. Only banks that at some time come under an enforcement action between 2000-2016 are used for matching. T-statistics in parentheses. Matching is done using a logistic model to generate a propensity score for being treated with regulatory action based on the covariates used in the above regressions (1 year asset growth, natural log of assets, nonperforming loans as share of assets, deposits as a share of assets) as well as all outcome variables (brokered deposits, listing service deposits, all three categories of term deposits; as shares of deposits). Then treated banks in one quarter are matched to untreated banks in the same quarter at the time of treatment based on this score. Matches are done based on normal kernel weighting, so that close matches are weighted proportionally more. We then observe the difference between treated and untreated 4 quarters after treatment. 
Figure 1: Deposit Balances

(a) Transaction
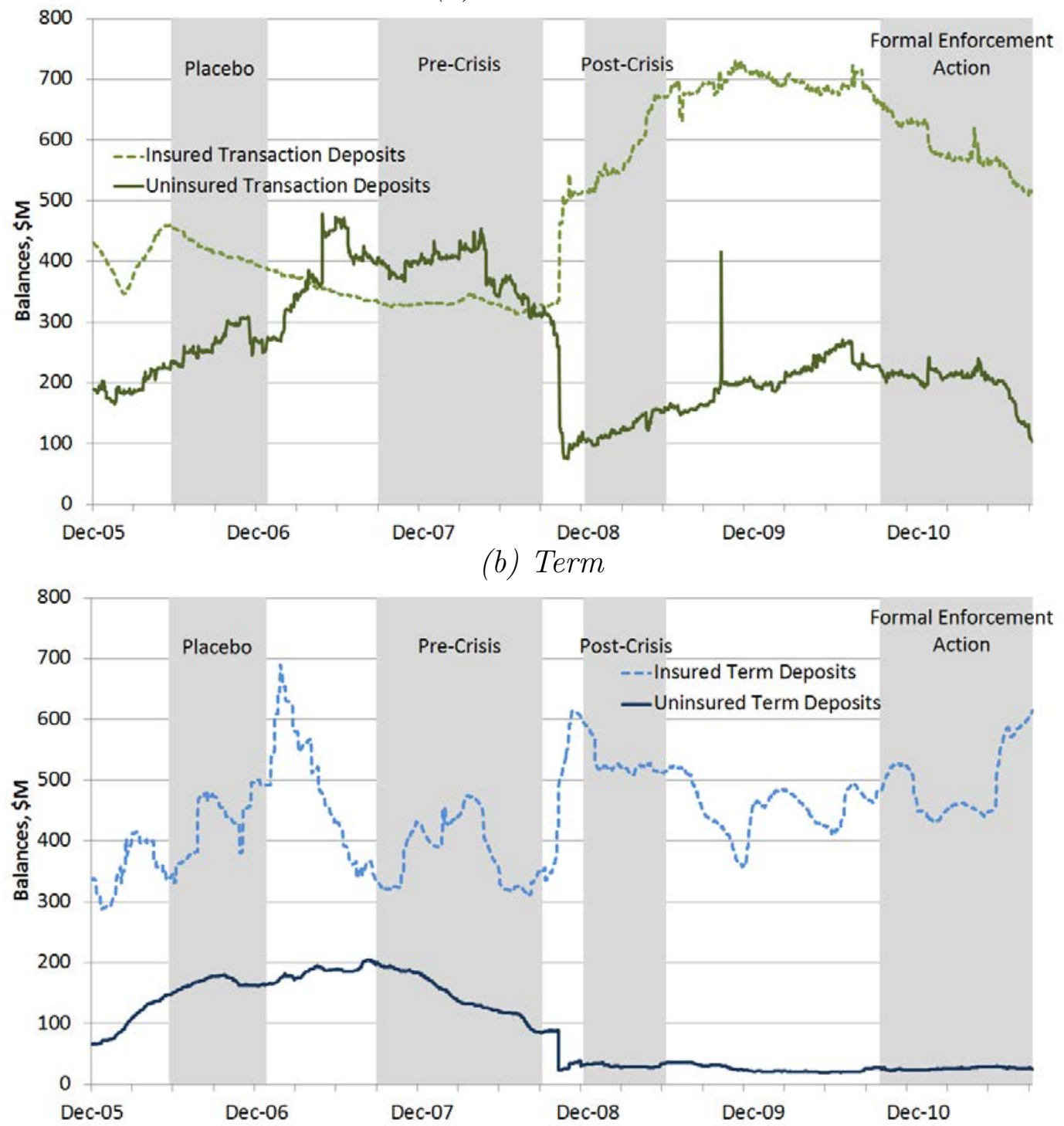

Total balances in transaction (top panel) and term (bottom panel) deposit accounts. Grey bars denote the time periods analyzed in the regressions of Section 3, and overlaid text identifies the name of each period. Note that the dramatic, brief spike in uninsured transaction deposits between the Post-Crisis and Formal periods reflects a single transaction in which another subsidiary of the bank's holding company passed funds through the bank in such a manner that they remained within the bank for a few days. 
Figure 2: Term Deposit Balances in Brokered, Placed, and Institutional Accounts

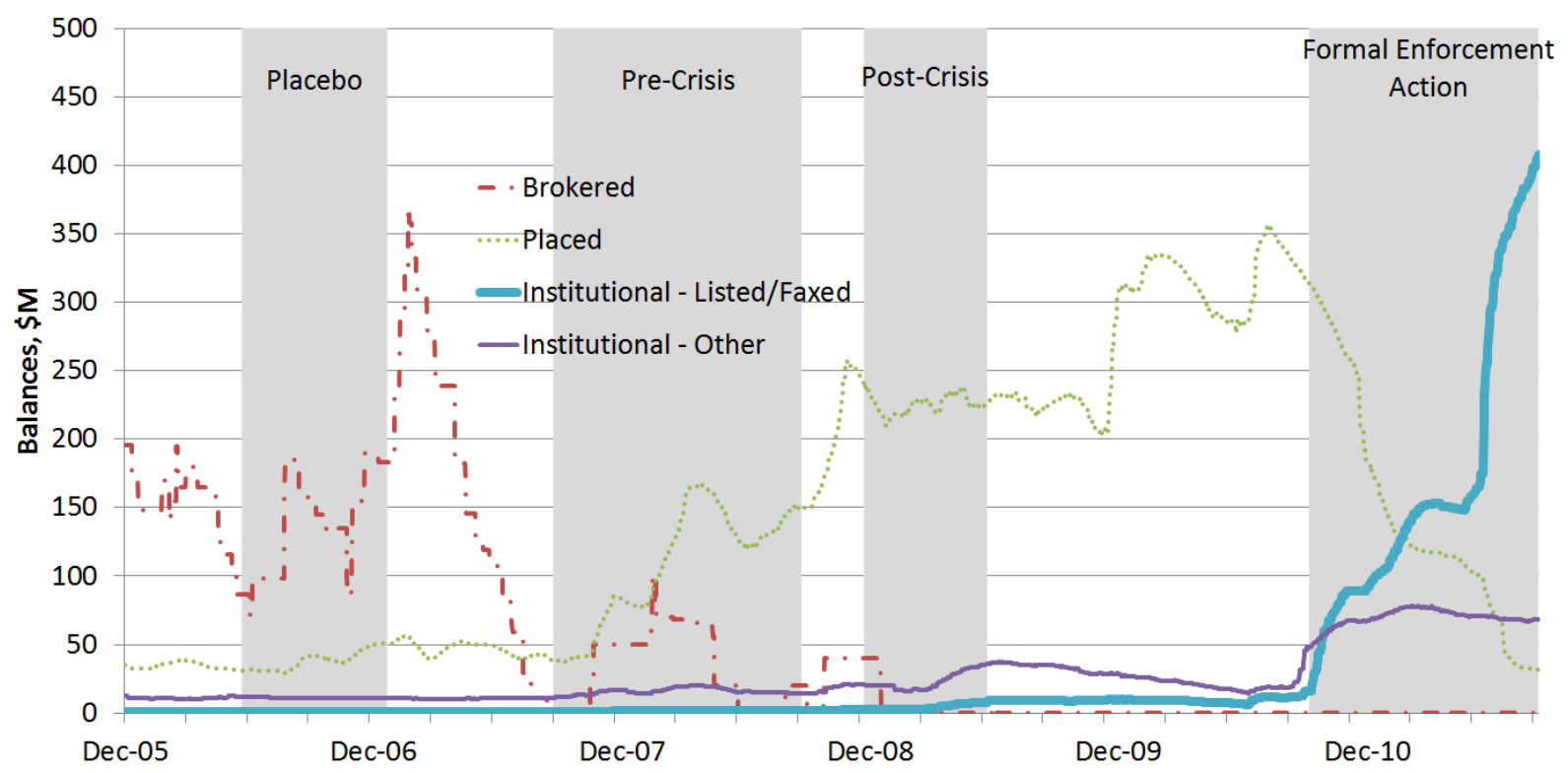

Term deposit account balances in brokered accounts (dash-dotted red), placed accounts (dotted green), institutional deposits obtained via rate listing services and faxes (bold blue), and other institutional deposits (solid, thin purple). Placed deposits are those placed by a third party on behalf the underlying depositor, where that third party does not meet the definition of deposit broker. Note that this is a different notion of placed deposits relative to that used in the regressions; here, we split placed and brokered deposits into two categories, whereas both were grouped as "placed" in the regressions. Among placed and brokered deposits, the underlying depositors are often not identified to the bank accepting the deposits. Grey bars denote the time periods analyzed in the regressions of Section 3 , and overlaid text identifies the name of each period. 
Figure 3: Term Deposit Balances From New Depositors

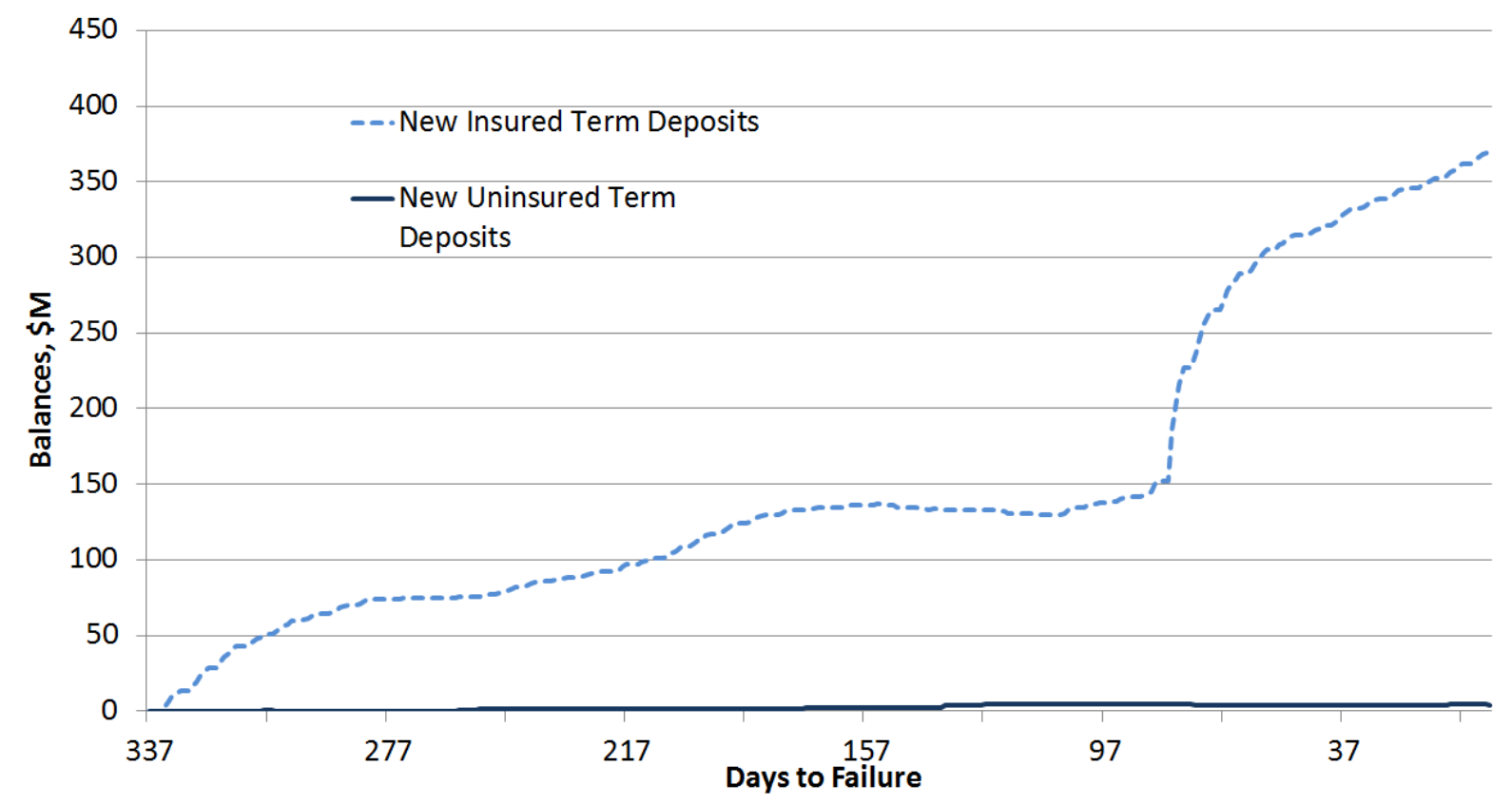

Balances in term deposit accounts from depositors who opened their first deposit account with the bank after the formal enforcement action — new depositors. 
Figure 4: 12-Month CD Rates Relative to the Market Distribution

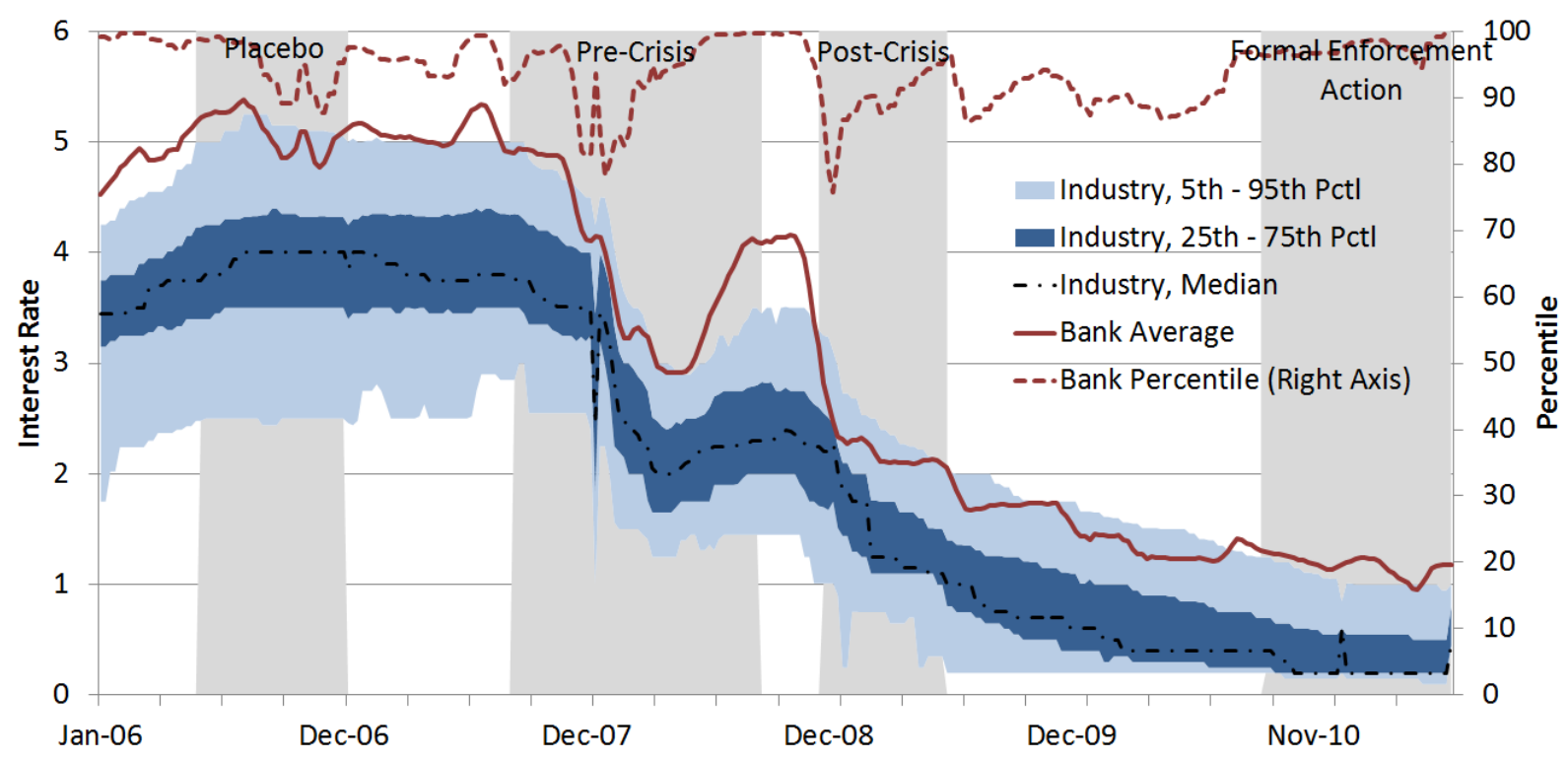

31-day moving average (fifteen days before, day of, and fifteen days after) of all rates offered by the bank on newly issued 12-month term deposits with balances below $\$ 100,000$ ("Bank Average;" solid red line) shown on the left axis, while the percentile relative to the distribution of banking industry rates (from RateWatch) for the same product is on the right axis. The bank average series is a measure of the rate which would have been faced by a depositor considering depositing funds at the bank that day. "Newly issued" term deposits include newly established term deposit accounts as well as rollovers of existing term deposits upon the expiration of the previous product. 
Figure 5: Impact of Regulatory Action on Funding Shares

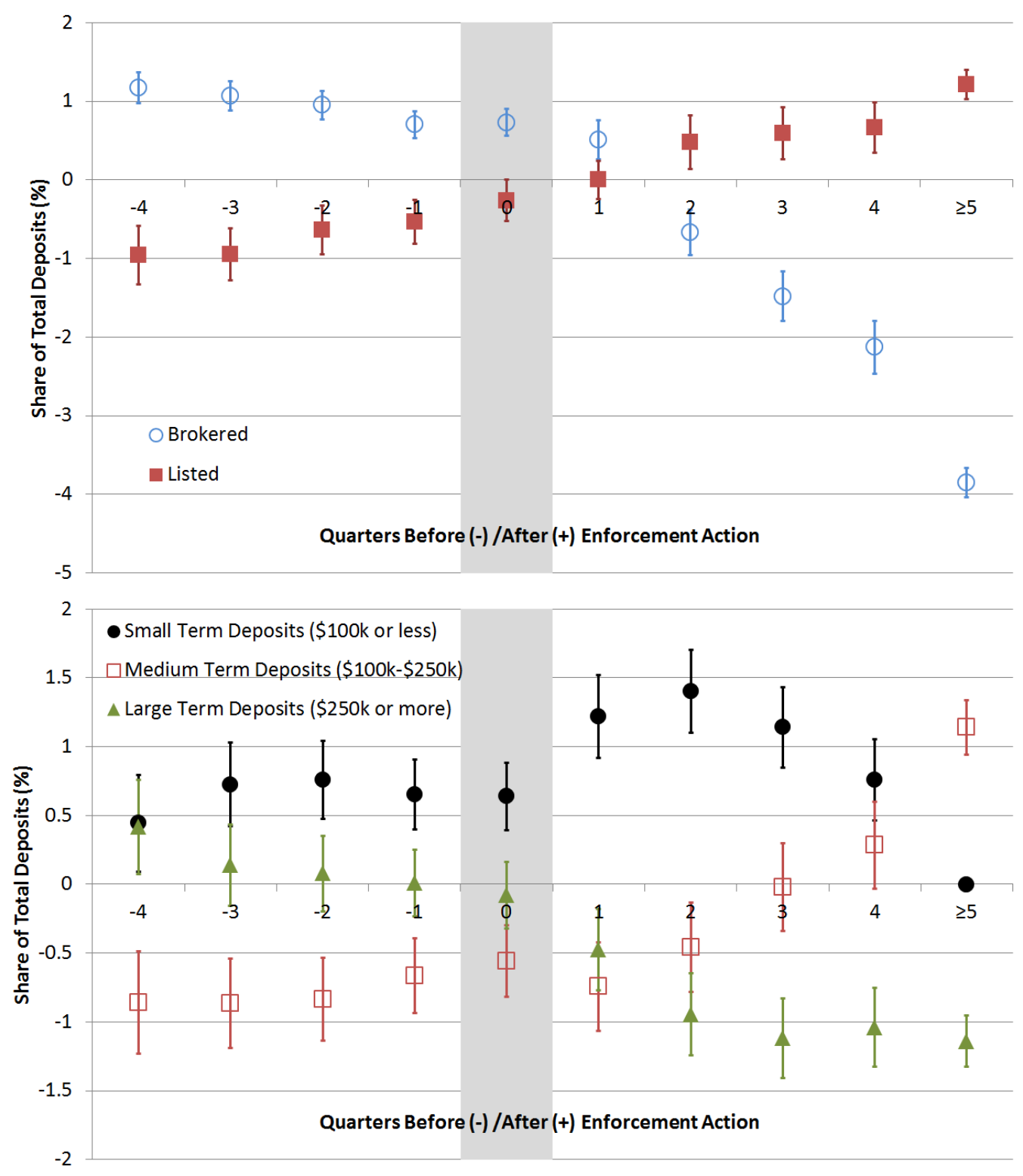

Graphical presentation of the impact of regulatory action on funding shares, using the estimates from Table 15. Small term deposits are those with balances of $\$ 100,000$ or less; medium term deposits are between $\$ 100,001$ and $\$ 250,000$; and large term deposits are those over $\$ 250,000$. Time period t is the quarter in which the enforcement action was issued. Error bands represent $95 \%$ asymptotic confidence intervals. 
Figure 6: LCR and NSFR Comparison

(a) $L C R$

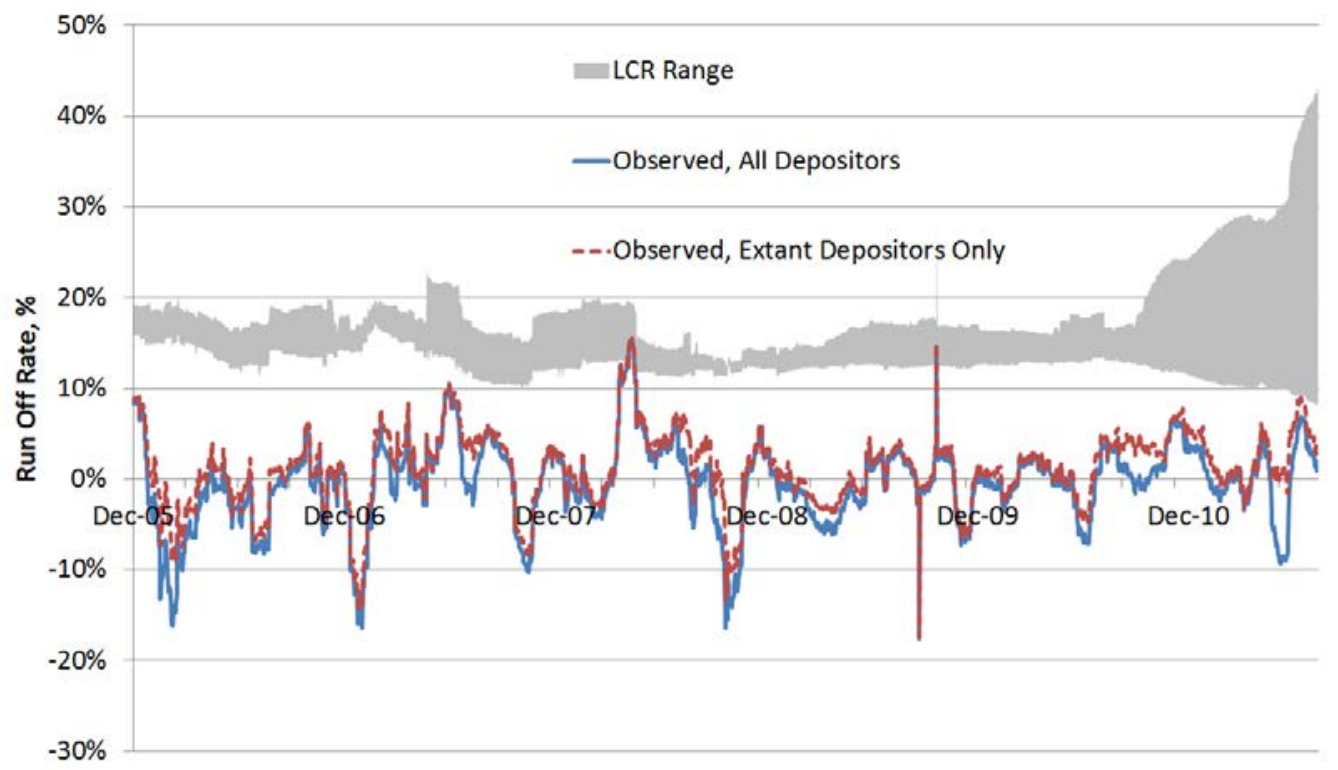

(b) NSFR

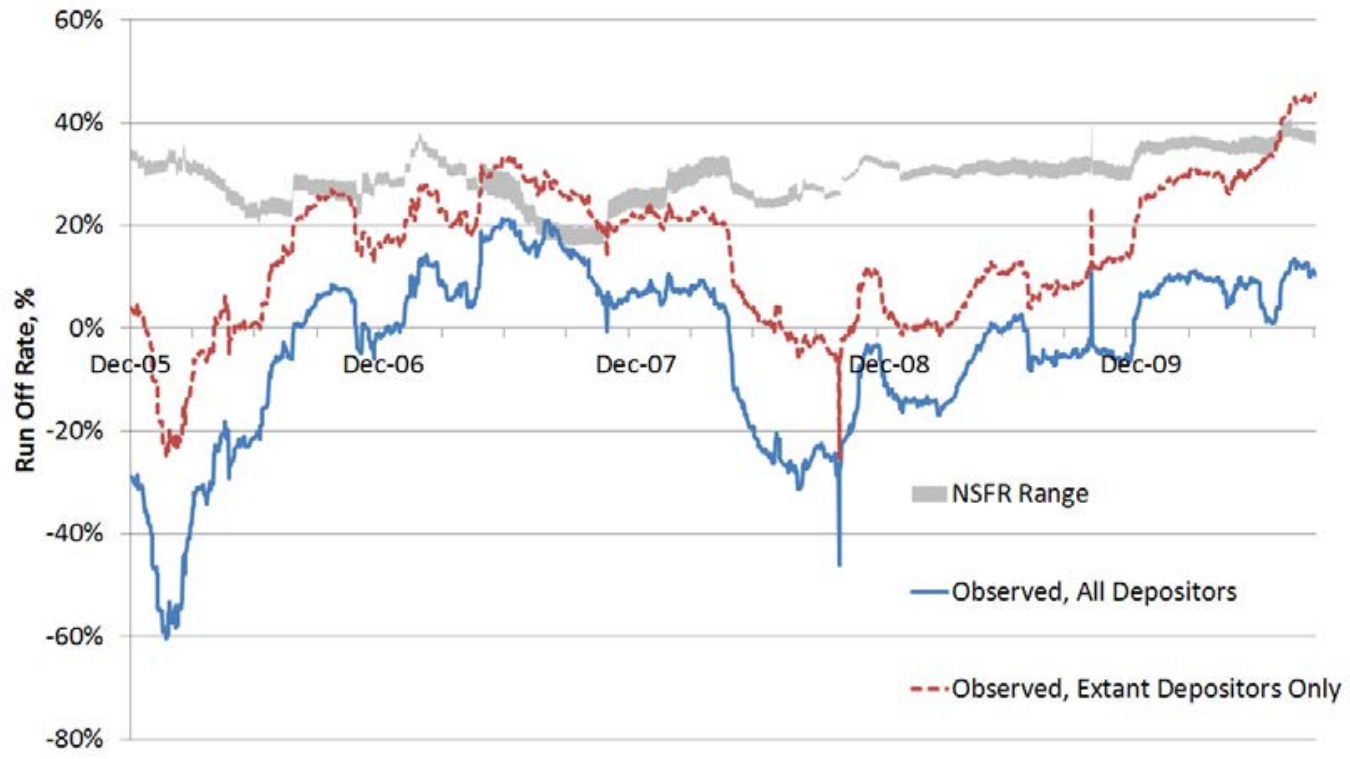

Observed run-off rates versus those assumed in the LCR (top panel) and NSFR (bottom panel). Grey intervals present ranges of run-off rates consistent with rules, where the ranges arise from uncertainty as to the share of business deposits which are considered operational; the extremes of the grey intervals correspond to the parameterizations wherein either all or no business deposits are operational. The solid blue and dotted red lines show observed runoff considering all depositors and only depositors who were at the bank as of the calculation date, respectively. All run-off rates are calculated in a forward-looking manner. That is, at any given date, the plotted values correspond to run-off observed over the following 30 days (LCR) or year (NSFR). 